\title{
Inhibition of N-Type Voltage-Activated Calcium Channels in Rat Dorsal Root Ganglion Neurons by P2Y Receptors Is a Possible Mechanism of ADP-Induced Analgesia
}

\author{
Zoltan Gerevich, ${ }^{1}$ Sebestyen J. Borvendeg, ${ }^{1}$ Wolfgang Schröder, ${ }^{2}$ Heike Franke, ${ }^{1}$ Kerstin Wirkner, ${ }^{1}$ \\ Wolfgang Nörenberg, ${ }^{1}$ Susanna Fürst, ${ }^{4}$ Clemens Gillen, ${ }^{3}$ and Peter Illes ${ }^{1}$ \\ ${ }^{1}$ Rudolf-Boehm-Institute of Pharmacology and Toxicology, University of Leipzig, D-04107 Leipzig, Germany, Departments of ${ }^{2}$ Pharmacology and \\ ${ }^{3}$ Molecular Pharmacology, Grünenthal GmbH, D-52099 Aachen, Germany, and ${ }^{4}$ Hungarian Academy of Sciences, Group of Neuropsychopharmacology, \\ Department of Pharmacology and Pharmacotherapy, Semmelweis University, H-1445 Budapest, Hungary
}

\begin{abstract}
Patch-clamp recordings from small-diameter rat dorsal root ganglion (DRG) neurons maintained in culture demonstrated preferential inhibition by ATP of high-voltage-activated, but not low-voltage-activated, $\mathrm{Ca}^{2+}$ currents $\left(I_{\mathrm{Ca}}\right)$. The rank order of agonist potency was UTP $>$ ADP $>$ ATP. ATP depressed the $\omega$-conotoxin GVIA-sensitive N-type current only. Pyridoxal-5-phosphate-6-azophenyl-2' ${ }^{\prime}{ }^{\prime}$ disulphonic acid (PPADS) and $2^{\prime}$-deoxy- $N^{6}$-methyladenosine $3^{\prime}, 5^{\prime}$-bisphosphate tetraammonium, two P2Y receptor antagonists, almost abolished the ATP-induced inhibition. Both patch-clamp recordings and immunocytochemistry coupled with confocal laser microscopy indicated a colocalization of functional $\mathrm{P} 2 \mathrm{X}_{3}$ and $\mathrm{P} 2 \mathrm{Y}_{1}$ receptors on the same DRG neurons. Because the effect of ATP was inhibited by intracellular guanosine $5^{\prime}$-0-(2-thiodiphosphate) or by applying a strongly depolarizing prepulse, $\mathrm{P}_{2} \mathrm{Y}_{1}$ receptors appear to block $I_{\mathrm{Ca}}$ by a pathway involving the $\beta \gamma$ subunit of a $\mathrm{G}_{\mathrm{q} / 11}$ protein. Less efficient buffering of the intracellular Ca ${ }^{2+}$ concentration $\left(\left[\mathrm{Ca}^{2+}\right]_{\mathrm{i}}\right)$ by reducing the intrapipette EGTA failed to interfere with the ATP effect. Fura-2 microfluorimetry suggested that ATP raised $\left[\mathrm{Ca}^{2+}\right]_{\mathrm{i}}$ by a $\mathrm{G} \alpha$-mediated release from intracellular pools and simultaneously depressed the high external potassium concentrationinduced increase of $\left[\mathrm{Ca}^{2+}\right]_{\mathrm{i}}$ by inhibiting $I_{\mathrm{Ca}}$ via $\mathrm{G} \beta \gamma$. Adenosine 5'-0-(2-thiodiphosphate) inhibited dorsal root-evoked polysynaptic population EPSPs in the hemisected rat spinal cord and prolonged the nociceptive threshold on intrathecal application in the tail-flick assay. These effects were not antagonized by PPADS. Hence, P2Y receptor activation by ADP, which is generated by enzymatic degradation of ATP, may decrease the release of glutamate from DRG terminals in the spinal cord and thereby partly counterbalance the algogenic effect of ATP.
\end{abstract}

Key words: ATP; P2Y receptor; calcium channel; dorsal root ganglion; patch clamp; analgesia

\section{Introduction}

Nociceptive information is carried from the peripheral processes of small-diameter dorsal root ganglion (DRG) neurons to their central terminals in the dorsal horn of the spinal cord. This information is then relayed to the secondary sensory neurons projecting into the upper CNS. Recent studies classified voltageactivated calcium channels (VACCs) in DRG neurons into three groups: (1) high-voltage-activated calcium channels (HVACCs), which included L-, N-, P-, and Q-types; (2) intermediate (Rtype) calcium channel; and (3) low-voltage-activated calcium channel (LVACC; T-type) (Varadi et al., 1999). On depolarization, VACCs allow the entry of calcium into the cell interior,

\footnotetext{
Received Sept. 1, 2003; revised Nov. 4, 2003; accepted Nov. 6, 2003.

This work was supported by the Bundesministerium für Bildung, Forschung und Technologie (Leitprojekt "Molekulare Schmerzforschung," 01GG981/0; Interdisziplinäres Zentrum für Klinische Forschung, 01KS9504, Projects C14 and Z10) and by the Deutsche Forschungsgemeinschaft (IL 20/11-1). We are grateful to H. Sobottka, S. Rosenow, H. Fischer, and B. Petter for technical assistance and Dr. J. Grosche for help with confocal microscopy. The expert linguistic correction of this manuscript by Dr. E. Wade is gratefully acknowledged.

Correspondence should be addressed to Dr. Peter Illes at the above address. E-mail: illp@medizin.uni-leipzig.de. DOI:10.1523/JNEUROSCI.4019-03.2004

Copyright $\odot 2004$ Society for Neuroscience $\quad$ 0270-6474/04/240797-11\$15.00/0
}

shaping excitability and initiating neurotransmitter release. Inhibition of calcium channel activity in DRG cells was shown to play an important role in pain transmission (Malmberg and Yaksh, 1994; Diaz and Dickenson, 1997).

Extracellular nucleotides (ATP, ADP, UTP, and UDP) have been shown to be signaling molecules in the CNS and PNS by acting via two types of $\mathrm{P} 2$ receptors termed $\mathrm{P} 2 \mathrm{X}$ (ligand-gated cationic channels) and P2Y (G-protein-coupled receptors) (Abbracchio and Burnstock, 1994; Ralevic and Burnstock, 1998). Currently, eight mammalian $\mathrm{P} 2 \mathrm{Y}$ receptors $\left(\mathrm{P}_{2} \mathrm{Y}_{1}, \mathrm{P}_{2} \mathrm{Y}_{2}, \mathrm{P} 2 \mathrm{Y}_{4}\right.$, $\mathrm{P}_{2} \mathrm{Y}_{6}, \mathrm{P}_{2} \mathrm{Y}_{11}, \mathrm{P} 2 \mathrm{Y}_{12}, \mathrm{P} 2 \mathrm{Y}_{13}$, and $\mathrm{P} 2 \mathrm{Y}_{14}$ ) have been cloned (von Kugelgen and Wetter, 2000; Communi et al., 2001; Nicholas, 2001; Abbracchio et al., 2003). A number of studies have demonstrated that P2Y receptors inhibit VACCs in neurons or in neuronally differentiated endocrine cell lines (Boehm, 2003). Activation of $\mathrm{G}_{\mathrm{i}}$-coupled endogenous $\mathrm{P}_{2} \mathrm{Y}_{12}$ receptors has been shown to inhibit N-type VACCs in PC12 cells (Kulick and von Kugelgen, 2002; Kubista et al., 2003). Moreover, agonists at heterologously expressed $\mathrm{P} 2 \mathrm{Y}_{1}, \mathrm{P}_{2} \mathrm{Y}_{2}, \mathrm{P}_{2} \mathrm{Y}_{4}$, and $\mathrm{P}_{2} \mathrm{Y}_{6}$ receptors inhibited $\mathrm{N}$-type VACCs in rat superior cervical ganglion neurons (Fillippov et al., 1998, 1999, 2000, 2003). 
$\mathrm{P}_{2} \mathrm{X}_{3}$ receptor mRNA is selectively expressed by a subpopulation of small-diameter DRG cells binding isolectin $\mathrm{B}_{4}$ and possessing also capsaicin-sensitive VR1 vanilloid receptors (Burgard et al., 1999; Ueno et al., 1999; Chizh and Illes, 2001). This neuronal population is thought to be involved in pain transmission; it displays rapidly desensitizing agonist-evoked currents most closely matching those of recombinant homomeric $\mathrm{P}_{2} \mathrm{X}_{3}$ receptors (Burgard et al., 1999). These small-fiber nociceptive neurons are believed to coexpress $\mathrm{P}_{2} \mathrm{Y}_{1}$ (Tominaga et al., 2001) or $\mathrm{P}_{2} \mathrm{Y}_{2}$ (Moriyama et al., 2003) and VR1 receptor mRNA; ATP may cause thermal hypersensitivity via a protein kinase $\mathrm{C}$-mediated positive interaction between $\mathrm{P} 2 \mathrm{Y}_{1} / \mathrm{P} 2 \mathrm{Y}_{2}$ and VR1 receptors.

The possible inhibition of VACCs by $\mathrm{P} 2 \mathrm{Y}$ receptors could be a key element in the regulation of neurotransmitter release from the central terminals of the sensory neurons and, thereby, in the modulation of pain transmission. Here, we report for the first time that endogenous $\mathrm{G}_{\mathrm{q}}$-coupled $\mathrm{P} 2 \mathrm{Y}\left(\mathrm{P}_{2} \mathrm{Y}_{1}\right)$ receptors selectively inhibit the N-type VACC by a voltage-dependent, membrane-delimited pathway. This effect, being observed in DRG neurons, leads to antinociception rather than pronociception under in vivo conditions. Part of these results have been published previously as a short communication (Borvendeg et al., 2003).

\section{Materials and Methods}

Animal experimentation. The present investigation was conducted in accordance with the principles outlined in the Declaration of Helsinki and the German law governing the care and use of laboratory animals and was approved by the representatives for animal care and use both in Leipzig (Rudolf-Boehm-Institute of Pharmacology, University of Leipzig) and Aachen (Department of Pharmacology, Grünenthal GmbH).

Preparation of DRG neuronal cultures. One-day-old and 7-week-old Wistar rats (own breed; WIST/Lei) were killed under $\mathrm{CO}_{2}$ and decapitated to obtain cell cultures of DRG neurons for electrophysiology and $\mathrm{Ca}^{2+}$ imaging, respectively. Previous experiments indicated that rats of the above age groups are optimal sources of neurons for each type of investigation. The isolation and culturing procedures of thoracic and lumbar DRG cells have been described in detail previously (Himmel et al., 2002). These cells were plated at a density of $2 \times 10^{4}$ cells $/ \mathrm{ml}$ onto poly-L-lysine-coated $(25 \mu \mathrm{g} / \mathrm{ml})$ glass coverslips. Cultures were maintained for $2-4 \mathrm{~d}$ at $37^{\circ} \mathrm{C}$ in a humidified atmosphere with $5 \% \mathrm{CO}_{2}$ before experimentation.

Whole-cell patch-clamp recordings in DRG neurons. Calcium currents $\left(I_{\mathrm{Ca}}\right)$ were recorded using the whole-cell configuration of the patchclamp technique by means of an Axopatch 200B amplifier (Axon Instruments, Foster City, CA). Patch electrodes (1.5-3 M $\Omega$ ) were filled with intracellular solution of the following composition (mM): $135 \mathrm{CsCl}, 2$ $\mathrm{MgCl}_{2}, 20 \mathrm{HEPES}, 11 \mathrm{EGTA}, 1 \mathrm{CaCl}_{2}, 1.5 \mathrm{Mg}$-ATP, and $0.3 \mathrm{Li}-\mathrm{GTP}, \mathrm{pH}$ 7.3 adjusted with $\mathrm{CsOH}$. When indicated, GTP was substituted with guanosine $5^{\prime}$-O-(2-thiodiphosphate) (GDP- $\beta$-S) $(0.3 \mathrm{~mm})$. In some experiments, $1.1 \mathrm{~mm}$ EGTA and $9.9 \mathrm{~mm} \mathrm{CsCl}$ were used to substitute $11 \mathrm{~mm}$ EGTA. The seal resistance was routinely $1 \mathrm{G} \Omega$. Residual pipette capacitance was compensated in the cell-attached configuration. The series resistance $\left(R_{\mathrm{s}}\right)$ was reduced by $60-80 \%$ using the inbuilt series resistance compensation circuit of the amplifier. The liquid junction potential $\left(V_{\mathrm{LJ}}\right)$ between the bath and pipette solutions at $22^{\circ} \mathrm{C}$ was calculated according to Barry (1994) and was found to be $-9.3 \mathrm{mV}$. Holding potential values given in this study were corrected for $V_{\mathrm{LJ}}$. The external recording solution consisted of (in mM) 155 TEA, $5 \mathrm{CaCl}_{2}, 0.8 \mathrm{MgCl}_{2}, 10 \mathrm{HEPES}$, and 11 glucose, $\mathrm{pH} 7.3$ adjusted with TEA-OH. Under these conditions, sodium and potassium currents were suppressed. In some experiments, a modified TEA solution was used containing (mM) $120 \mathrm{NaCl}, 20 \mathrm{TEA}, 5 \mathrm{CaCl}_{2}$, $0.8 \mathrm{MgCl}_{2}, 10$ HEPES, 11 glucose, and $0.5 \mu \mathrm{M}$ TTX, pH 7.3 adjusted with TEA-OH.

$I_{\mathrm{Ca}}$ was elicited repetitively from a holding potential of $-90 \mathrm{mV}$ by rectangular voltage steps, $80 \mathrm{msec}$ in duration, to $-10 \mathrm{mV}$, one voltage step every $20 \mathrm{sec}$. In some experiments, strongly depolarizing prepulses to $+120 \mathrm{mV}$ from the holding potential of $-90 \mathrm{mV}$ were applied for 20 msec. The interval between the prepulse and the test pulse was $5 \mathrm{msec}$. Current amplitudes were measured isochronically $15 \mathrm{msec}$ from the onset of the test pulse near to the peak of the currents. Current-voltage relationships for $I_{\mathrm{Ca}}$ were obtained by applying fast $(320 \mathrm{msec})$ ramp-like voltage pulses from -90 to $+70 \mathrm{mV}$ every $30 \mathrm{sec}$.

Current recordings were low-pass filtered at $2 \mathrm{kHz}$ using the built-in four-pole low-pass Bessel filter of the amplifier and sampled at $10 \mathrm{kHz}$ via a Digidata 1200 interface (Axon Instruments). Recordings were corrected for linear capacitance and leakage currents by the $-\mathrm{P} / 4$ function of the pClamp 8.0 software (Axon Instruments) used otherwise for data acquisition and analysis.

All experiments were performed at room temperature $\left(20-24^{\circ} \mathrm{C}\right)$. A pressure-operated, computer-controlled rapid drug application device (DAD-12; Adams and List, Westbury, NY) was used for drug administration. After a control period (1-2 min), P2Y receptor agonists were applied for $2 \mathrm{~min}$ and then washed out. P2Y receptor antagonists were added $7 \mathrm{~min}$ before agonist application and were maintained until the end of the experiment. VACC blockers were added as described in the Results.

Concentration-response curves were fitted using the following logistic function (Sigma Plot; SPSS, Erkrath, Germany):

$$
I=I_{\min }+\left(I_{\max }-I_{\min }\right)\left[1+\left(\mathrm{IC}_{50}+\text { agonist }\right)^{\mathrm{n}}\right]
$$

where $I$ is the steady-state inhibition produced by the agonist; $I_{\max }$ and $I_{\min }$ are the maximal and minimal inhibition, respectively; $n$ is the Hill coefficient; and $\mathrm{IC}_{50}$ is the concentration of agonist producing $50 \%$ of $I_{\max }$.

In a few experiments, DRG neurons of Sprague Dawley rats were prepared and cultured by using identical procedures to those described for Wistar rats. Both the inhibition of $I_{\mathrm{Ca}}$ by ATP and the interaction of this agonist with PPADS were indistinguishable in DRGs obtained from the two different strains of rats.

Intracellular $\mathrm{Ca}^{2+}$ measurements in DRG neurons. DRG cell cultures were loaded for $50-60 \mathrm{~min}$ at $37^{\circ} \mathrm{C}$ in the dark with the cell permeant acetoxymethyl ester of the fluorescent $\mathrm{Ca}^{2+}$ indicator fura-2 $(1 \mu \mathrm{M})$. Simultaneously, cells were exposed to FITC-labeled Bandeireia simplicifolia isolectin $\mathrm{IB}_{4}(0.25 \mu \mathrm{g} / \mathrm{ml}$; Sigma $)$. To remove excess extracellular fura- 2 and $\mathrm{IB}_{4}$, glass coverslips were washed several times with extracellular medium (in mM: $140 \mathrm{NaCl}, 4.5 \mathrm{KCl}, 2 \mathrm{CaCl}_{2}, 1 \mathrm{MgCl}_{2}, 10 \mathrm{HEPES}$, and 10 glucose, $\mathrm{pH}$ adjusted to 7.4 with $\mathrm{NaOH}$ ) and were allowed to rest for $30 \mathrm{~min}$ at room temperature protected from light. $\mathrm{Ca}^{2+}$ imaging experiments and the quantification of FITC- $\mathrm{IB}_{4}$ labeling of DRG cells were performed as described previously (Himmel et al., 2002). In short, intracellular fura- 2 was alternately excited at $340 \mathrm{~nm}$ and at $380 \mathrm{~nm}$, and the emitted light was measured at a wavelength of $510 \mathrm{~nm}$. The fluorescence ratio $(340 / 380)$ provides a relative measure of the cytosolic-free $\mathrm{Ca}^{2+}$ concentration $\left(\left[\mathrm{Ca}^{2+}\right]_{\mathrm{i}}\right)$. Drugs and the washout solution were applied via the flush valves of DAD-12. The TILL vision software (release 3.3; Till Photonic CS, Graefelfing, Germany) was used for data acquisition, system control, and off-line analysis.

DRG neurons were depolarized with a high $\mathrm{K}^{+}$-containing extracellular medium (in mм: $94.5 \mathrm{NaCl}, 50 \mathrm{KCl}, 2 \mathrm{CaCl}_{2}, 1 \mathrm{MgCl}_{2}, 10 \mathrm{HEPES}$, and 10 glucose, $\mathrm{pH}$ adjusted to 7.4 with $\mathrm{NaOH}$ ) for 2 sec every 5 min. P2 receptor agonists were applied $60 \mathrm{sec}$ before, during, and after the third $\mathrm{K}^{+}$superfusion for a total of $90 \mathrm{sec}$. The last response to $\mathrm{K}^{+}$before superfusion with the $\mathrm{P} 2$ receptor agonist was considered to be $100 \%$ (control); the response to a $\mathrm{P} 2$ receptor agonist, or the response to $\mathrm{K}^{+}$in the presence of a $\mathrm{P} 2$ receptor agonist, was expressed as a percentage of the control response. P2 receptor antagonists were applied $10 \mathrm{~min}$ before the first stimulation with a high $\mathrm{K}^{+}$medium and were maintained until the end of the experiment.

In the experimental protocols aimed at examining the effect of $\mathrm{Ca}^{2+}$. free extracellular medium, $\mathrm{K}^{+}$or the $\mathrm{P} 2$ receptor agonists were administered five times for $10 \mathrm{sec}$ every $10 \mathrm{~min}$. $\mathrm{A} \mathrm{Ca}^{2+}$-free external medium supplemented with EGTA ( $1 \mathrm{mM}$ ) was applied 3 min before, during, and after the third superfusion with $\mathrm{K}^{+}$or the $\mathrm{P} 2$ receptor agonists, for a total of $5 \mathrm{~min}$. The last response to $\mathrm{K}^{+}$or the $\mathrm{P} 2$ receptor agonists before the 
application of a $\mathrm{Ca}^{2+}$-free external medium was considered to be $100 \%$ (control); responses to these stimuli in a $\mathrm{Ca}^{2+}$-free medium were expressed as percentages of the control response.

Electrophysiology in hemisected spinal cord preparations. Immature Sprague Dawley rats (Janvier, Le Genest Saint Isle, France) of either sex (2-10 d old; $8-20 \mathrm{gm}$ ) were anesthetized with urethane (1.5 gm/ $\mathrm{kg}$, i.p.), and after decapitation, spinal cords were removed and hemisected along the midline. Sprague Dawley, rather than Wistar, rats were used to have a better comparability with the behavioral data (see below). The preparation was then placed into a recording chamber and perfused at room temperature at $2 \mathrm{ml} / \mathrm{min}$ with external medium containing (mM): 118 $\mathrm{NaCl}, 3 \mathrm{KCl}, 1.5 \mathrm{CaCl}_{2}, 1.25 \mathrm{MgSO}_{4}, 24 \mathrm{NaHCO}_{3}$, and 12 glucose, gassed with $95 \% \mathrm{O}_{2} / 5 \% \mathrm{CO}_{2}$. The stimulating electrode was in contact with the L4 or L5 dorsal root and the recording electrode with the corresponding ipsilateral ventral root (Faber et al., 1997).

Two different protocols of electrical stimulation were used: lowintensity stimuli (single pulses of $0.5 \mathrm{msec}$ duration at three times the threshold intensity) and high-intensity stimuli (single pulses at 16 times the threshold intensity). In the hemisected spinal cord preparation, several components of population dorsal root-evoked ventral root potentials were observed. The low-intensity stimulation evoked an initial monosynaptic compound action potential [monosynaptic reflex (MSR); duration up to $200 \mathrm{msec}$ ] superimposed on a polysynaptic population EPSP that lasted for up to $4 \mathrm{sec}$. These two responses were mediated by A-fibers. Single high-intensity stimuli evoked prolonged, presumably both A- and C-fiber-mediated, polysynaptic EPSPs lasting $\sim 40 \mathrm{sec}$. The averages of five consecutive low-intensity sweeps (interpulse interval, 6 $\mathrm{sec}$ ), followed by the averages of five consecutive high-intensity sweeps (interpulse interval, $18 \mathrm{sec}$ ) were obtained. Signals were digitized, stored, and analyzed using commercially available software (DASYLAB; Synotech, Linnich, Germany). The following parameters were analyzed: the peak amplitude of the MSR as well as the areas under the curve of lowand high-intensity EPSPs. Drugs were dissolved in external medium and applied via superfusion. Increasing concentrations were tested on the same preparation in a cumulative manner with equilibration periods sufficient to reach a plateau of the effect (typically $20 \mathrm{~min}$ for each drug concentration or compound). The long equilibration period is attributable to the slow diffusion of the ligands into the tissue.

Immunofluorescence. After fixation with ice-cold methanol for $10 \mathrm{~min}$ at $4^{\circ} \mathrm{C}$, washing with HBSS for $5 \mathrm{~min}$, and blocking with 5\% FCS (Seromed, Berlin, Germany) and 0.1\% Triton X-100 in TBS (0.05 $\mathrm{M} ; \mathrm{pH}$ 7.6), the cell cultures were incubated in a first step with an antibody mixture of rabbit anti-P2Y $\mathrm{Y}_{1}$ (1:400; Alomone, Jerusalem, Israel) and guinea pig anti- $\mathrm{P}_{2} \mathrm{X}_{3}$ receptor antibodies (1:1000; Neuromics, Minneapolis, MN) in TBS containing $0.1 \%$ Triton X-100 and 5\% FCS overnight at $4^{\circ} \mathrm{C}$. The secondary antibodies used for the simultaneous localization of the two primary antisera were Cy5-conjugated goat anti-rabbit IgG (1: 400; Jackson ImmunoResearch, Baltimore, MD) and Cy2-conjugated goat anti-guinea pig IgG (1:400; Jackson ImmunoResearch), respectively, and the cultures were incubated for $2 \mathrm{hr}$ at room temperature. Then, after washing with TBS, the cultures were incubated with goat anti-VR1 IgG (R-18; 1:1500; Santa Cruz Biotechnology, Santa Cruz, CA) in TBS containing $0.1 \%$ Triton X-100 and 5\% FCS for $24 \mathrm{hr}$ at $4^{\circ} \mathrm{C}$. As a secondary antibody, Cy3-conjugated donkey anti-goat $\operatorname{IgG}(1: 1000$; Jackson ImmunoResearch) was used for $2 \mathrm{hr}$ at room temperature.

After washing, all stained cultures were dehydrated in a series of graded ethanol, processed through $\mathrm{N}$-butylacetate and covered with entellan (Merck, Darmstadt, Germany). Control experiments were performed without primary antibody or by preadsorption of the antibody with the immunizing peptides. The suppliers of all commercially available antibodies confirmed the selectivity of their preparations by Western blotting.

The triple immunofluorescence was investigated by means of a laser scanning confocal microscope (LSM 510; Zeiss, Oberkochen, Germany) at an excitation wavelength of $633 \mathrm{~nm}$ (helium/neon2, blue Cy5 immunofluorescence), $543 \mathrm{~nm}$ (helium/neon1, red Cy3 immunofluorescence), and $488 \mathrm{~nm}$ (argon, yellow-green Cy2 immunofluorescence). The three reaction products were distinguished by their different fluorescence: the $\mathrm{P} 2 \mathrm{X}_{3}$ receptor by the green $\mathrm{Cy} 2$ immunofluorescence, the
VR1 receptor by the red Cy3 immunofluorescence, and the $\mathrm{P} 2 \mathrm{Y}_{1}$ receptor by the blue Cy5 immunofluorescence. Quantification of immunofluorescence was performed by randomly selecting neurons of $20-35 \mu \mathrm{m}$ diameter At least 100 neurons were counted in four DRG cultures, each obtained from a different animal.

Tail-flick test. Male Sprague Dawley rats (Janvier) weighing 204-270 gm were used. The animals were housed under standardized humidity, temperature, and lighting conditions. The animals had access to water and food ad libitum.

The tail-flick test was performed according to D'Amour and Smith (1941) with a light beam analgesia meter (Rhema Labortechnik, Hofheim, Germany). Briefly, various doses of adenosine 5'-O-(2thiodiphosphate) (ADP- $\beta-S$ ) were injected intrathecally between L1 and L3 under light diethylether (Merck) anesthesia. A radiant heat beam was focused onto the dorsal surface of the restrained rat's tail $\sim 2-4 \mathrm{~cm}$ apart from the root. The intensity of the radiant heat beam was adjusted to $40 \%$ of the maximum value, resulting in a mean control latency for tail withdrawal of $7.5 \pm 1.5 \mathrm{sec}(n=100)$. To avoid tissue damage, the cutoff time was adjusted to $30 \mathrm{sec}$. The antinociceptive effect was calculated according to the following equation:

$$
\operatorname{MPE}[\%]=\frac{t_{1}-t_{\mathrm{c}}}{t_{\text {cutoff }}-t_{\mathrm{c}}} \times 100 \%
$$

Where MPE is the maximum possible effect, $t_{1}$ is the latency time of tail withdrawal, $t_{\mathrm{c}}$ is the control latency, and $t_{\text {cutoff }}$ is the cutoff time. The $\mathrm{ED}_{50}$ value is the agonist dose producing $50 \%$ of the MPE. Both ADP- $\beta-S$ and PPADS were dissolved in $0.9 \% \mathrm{NaCl}$.

The latency of the tail withdrawal response was measured before $\left(t_{\mathrm{c}}\right)$ and at 10,20,30,60, 90, and 120 min after drug application. Control animals received an intrathecal injection of $0.9 \% \mathrm{NaCl}$. Various doses of ADP- $\beta$-S were applied intrathecally under light ether anesthesia; the antagonist PPADS was also injected intrathecally, $10 \mathrm{~min}$ before the application of ADP- $\beta$-S. Accordingly, PPADS controls were injected with $0.9 \% \mathrm{NaCl}$ intrathecally instead of ADP- $\beta$-S. The application volumes were $5 \mu \mathrm{l} /$ animal. Ten animals were used per group.

In these series of experiments, Sprague Dawley rather than Wistar rats were used, because long-lasting experience indicates that this strain is more appropriate for all kinds of behavioral investigations. Preliminary experiments showed that ADP- $\beta$-S applied intrathecally prolonged the tail-flick latency in Wistar and Sprague Dawley rats to a comparable extent.

Data analysis. Data were presented as means \pm SEM. Student's $t$ test (unpaired) or ANOVA, followed by Dunnett's post hoc test, as appropriate, was applied to the data to determine statistical significance. A probability level of $\leq 0.05$ was considered to be statistically significant.

Drugs. Chemicals used were: ATP, ADP, ADP- $\beta-S, \alpha, \beta-$ methylenadenosine $\quad 5^{\prime}$-triphosphate $(\alpha, \beta$-meATP $), \quad 2^{\prime}, 3^{\prime}$-O- $(2,4,6-$ trinitrophenyl) adenosine $5^{\prime}$-triphosphate (TNP-ATP), GTP, GDP- $\beta$-S, BAPTA, suramin hexasodium salt, TEA, TTX, $\omega$-conotoxin GVIA $(\omega$ CTX), $\omega$-agatoxin IVA ( $\omega$-Aga), isolectin $\mathrm{B}_{4}$ (Sigma, Deisenhofen, Germany), $2^{\prime}$-deoxy- $N^{6}$-methyladenosine $3^{\prime}, 5^{\prime}$-bisphosphate tetraammonium (MRS 2179), PPADS (Tocris Cookson, Bristol, UK), fura-2 (Molecular Probes, Leiden, The Netherlands), and AR-C69931MX (AstraZeneca, Wilmington, DE; a gift from Dr. M. Wayne).

Samples of ATP (99\% ATP, 1\% ADP) and UTP (82\% UTP, 18\% UDP) were checked for purity by HPLC before use. According to information from the supplier, the only significant impurity in ADP- $\beta$-S was identified as AMP. Therefore, an impurity of ATP was certainly not responsible for any effect of the UTP or ADP- $\beta$-S samples.

\section{Results \\ Inhibition of the N-type $\mathrm{Ca}^{2+}$ current of DRG neurons by $\mathrm{P}_{2} \mathrm{Y}_{1}$ receptors}

Figure $1 \mathrm{Aa}$ shows representative tracings of whole-cell $I_{\mathrm{Ca}}$ flowing through VACCs in cultured small-diameter $(20-35 \mu \mathrm{m})$ DRG neurons. The currents were evoked by a depolarizing ramp from a holding potential of -90 to $+70 \mathrm{mV}$. Currents through LVACCs were activated at $-60 \mathrm{mV}$ and reached their maximum 

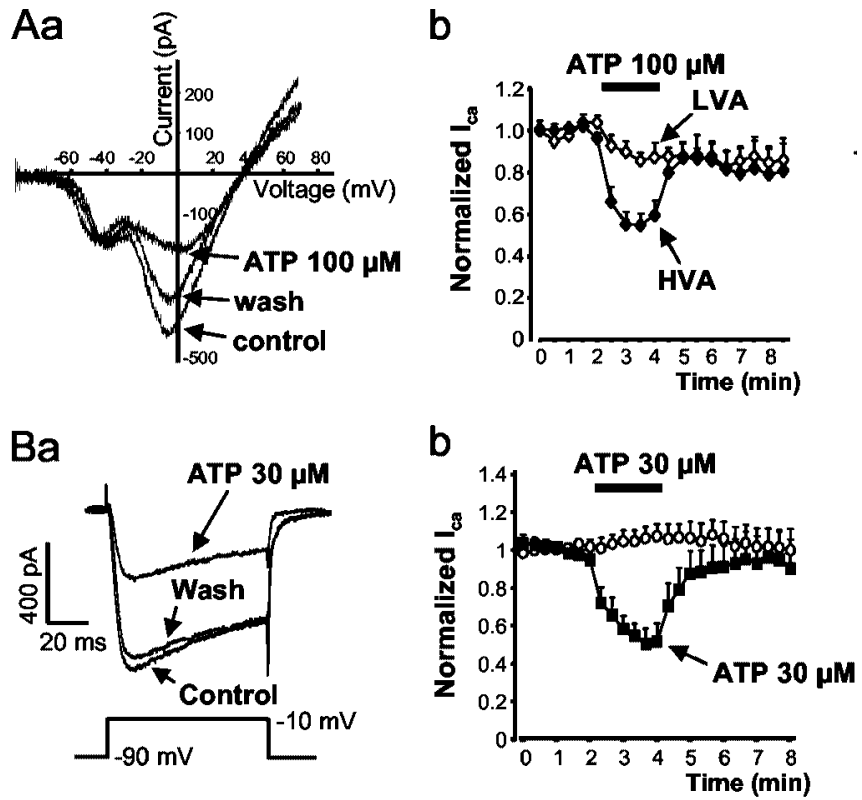

Figure 1. Inhibition of VACCs by ATP. Calcium currents were recorded in rat DRGs using the whole-cell configuration of the patch-clamp technique. A, ATP $(100 \mu \mathrm{m})$ inhibited HVACCs but not LVACCs. Depolarizing voltage ramps of $320 \mathrm{msec}$ duration from the holding potential of -90 to $+70 \mathrm{mV}$ were applied every 30 sec to evoke $\mathrm{Ca}^{2+}$ currents. Currents through LVACCs were activated at $-60 \mathrm{mV}$ and reached their maximum at $-40 \mathrm{mV}$. HVACCs had an activation threshold at $-40 \mathrm{mV}$ (as estimated by extrapolation) and peaked at $-10 \mathrm{mV}$. Aa, Representative tracing. Current responses before (control), during, and 2 min after (washout) the application of ATP (100 $\mu \mathrm{M})$ for $2 \mathrm{~min}$. Ab, Peak HVA and LVA Ca ${ }^{2+}$ current amplitudes normalized with respect to the mean of the first five control responses evoked by repetitive ramp-like voltage pulses. Data are mean \pm SEM of five experiments. $B$, HVACC currents were evoked by depolarization from -90 to $-10 \mathrm{mV}$ for $80 \mathrm{msec}$ every $20 \mathrm{sec}$. Ba, Representative tracings. Current responses before (control), during, and $2 \mathrm{~min}$ after (washout) the application of ATP $(100 \mu \mathrm{M})$ for $2 \mathrm{~min} . \mathrm{Bb}_{,} \mathrm{Ca}^{2+}$ current amplitudes normalized with respect to the mean of the first seven control responses evoked by repetitive voltage steps. Data are mean \pm SEM of six experiments.

at $-40 \mathrm{mV}$. The HVACCs had an activation threshold at $-40 \mathrm{mV}$ (as estimated by extrapolation) and peaked at $-10 \mathrm{mV}$. The mixed P2X/P2Y receptor agonist ATP $(100 \mu \mathrm{M})$ markedly inhibited HVACCs and only slightly affected LVACCs (Fig. 1Aa,Ab). The effect of ATP was reversible on washout. ATP by itself did not alter the holding current, indicating that the opening of the cationic $\mathrm{P} 2 \mathrm{X}_{3}$ receptor channels failed to cause inward current when $\mathrm{TEA}^{+}$was used to completely replace $\mathrm{Na}^{+}$in the external medium. HVACC currents were also activated by a single depolarizing step from -90 to $-10 \mathrm{mV}$ for $80 \mathrm{msec}$ (Fig. $1 \mathrm{Ba}$ ). The cationic species entering the cells appeared to be predominantly $\mathrm{Ca}^{2+}$, because the inorganic $\mathrm{Ca}^{2+}$ antagonist $\mathrm{Co}^{2+}(1 \mathrm{mM})$ almost abolished the inward current (data not shown). Voltage steps delivered every $20 \mathrm{sec}$ caused reproducible inward HVACC current amplitudes during the whole measurement period (Fig. $1 \mathrm{Bb})$. ATP $(30 \mu \mathrm{M})$ inhibited the current amplitude in a manner completely reversible on washout with ATP-free medium (Fig. $1 B a, B b)$. In the presence of ATP $(30 \mu \mathrm{M})$, the current activation showed a tendency to become slower, which, however, did not reach the level of statistical significance. The rise time from 10 to $90 \%$ of the peak current amplitude $\left(\tau_{(10-90)}\right)$ was $6.3 \pm 1.5 \mathrm{msec}$ before, $8.9 \pm 2.1 \mathrm{msec}$ during, and $6.6 \pm 2.0 \mathrm{msec}$ after the application of ATP $(n=6 ; p>0.05)$ (Fig. $1 B a)$. This tendency did not become statistically significant despite increasing the concentration of ATP from 30 to $100 \mu \mathrm{M}$ ( $n=6$; data not shown).
$\mathrm{Aa}$

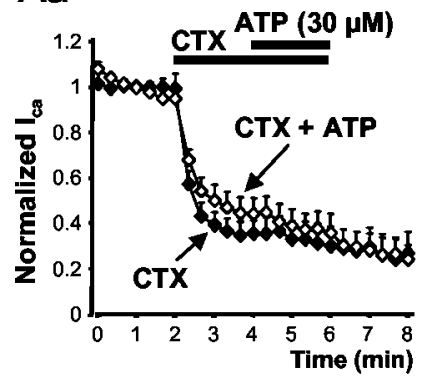

b

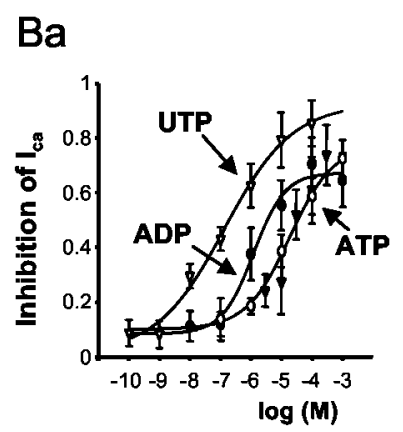

b

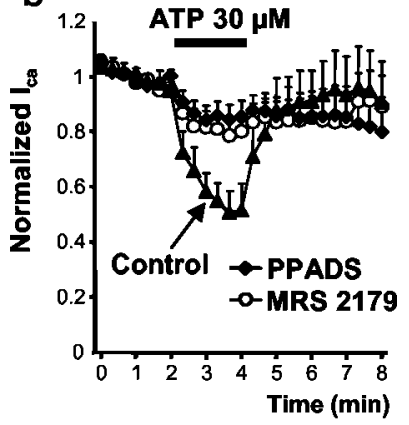

Figure 2. Inhibition of HVACCs by the P2Y receptor agonists ATP, ADP, and UTP, and interaction of ATP with the P2Y receptor antagonists PPADS and MRS 2179. Calcium currents were recorded in rat DRGs using the whole-cell configuration of the patch-clamp technique. Voltage steps were made from a holding potential of -90 to $-10 \mathrm{mV}$ every 20 sec to induce inward currents. Aa, ATP (30 $\mu \mathrm{m})$ did not affect the $\omega$-CTX-insensitive HVACC currents. $\omega$-CTX alone caused a rapidly developing inhibition of $I_{\mathrm{Ca}}$ which did not recover on washout of the toxin for 2 min. $\mathrm{Ca}^{2+}$ current amplitudes in $A a$ and $B b$ were normalized with respect to the mean of the first seven control responses evoked by repetitive voltage steps. Data are mean $\pm S E M$ of six $(\diamond)$ and seven $(\diamond)$ experiments. Ab, Summary data showing the effect of ATP $(30 \mu \mathrm{m} ; n=6)$ after a 2 min application. Respective data for $\omega$-CTX $(0.5 \mu \mathrm{m} ; n=6), \omega$-CTX $(0.5 \mu \mathrm{m})$ plus ATP (30 $\mu \mathrm{m} ; n=7)$, and $\omega$-Aga $(0.4 \mu \mathrm{m} ; n=6)$ after a 4 min application. The bars are means \pm SEM expressed as a percentage of the mean control currents $(n=7)$ before drug application. ${ }^{*} p<0.05$, statistically significant difference from $100 \%$ (predrug control value). Ba, Concentration-response curves for the cumulative application of $\operatorname{ATP}(\bigcirc ; n=9), \operatorname{ADP}(0 ; n=8)$, and UTP $(\nabla ; n=6)$. After recording of seven stable control currents, cumulatively increasing concentrations of ATP, ADP, or UTP were applied for 2 min each. The agonist-induced depression of the HVACC current was normalized to the mean of the seven control currents. Bb, Antagonism by PPADS and MRS 2179 of inhibition by ATP $(30 \mu \mathrm{M})$ of $I_{C \cdot}$. PPADS $(30 \mu \mathrm{m})$ and MRS 2179 (30 $\mu \mathrm{m}$ ) were applied $7 \mathrm{~min}$ before the application of ATP.

A second series of experiments were designed to determine which HVACC current types were inhibited by ATP. $\omega$-CTX $(0.5$ $\mu \mathrm{M}$ ), a selective blocker of N-type HVACCs, caused a rapid inhibition of $\mathrm{Ca}^{2+}$ current amplitudes that did not recover within 2 min after washout of the toxin (Fig. $2 \mathrm{Aa}$ ). The $\omega$-CTX-sensitive $\mathrm{N}$-type fraction contributed $\sim 65 \%$ of the total $I_{\mathrm{Ca}}$. The $\omega$-CTXinduced maximum inhibition was not increased further by the application of ATP $(30 \mu \mathrm{M})$ (Fig. $2 A a, A b)$, suggesting that ATP only acts at the N-type $\mathrm{Ca}^{2+}$ current $\left(I_{\mathrm{Ca}(\mathrm{N})}\right)$. In fact, the P/Qtype HVACC blocker $\omega$-Aga $(0.4 \mu \mathrm{M})$ did not influence $\mathrm{Ca}^{2+}$ current amplitudes when applied alone (Fig. $2 A b$ ), arguing against a major contribution of this current type to total $I_{\mathrm{Ca}}$ under the present experimental conditions (but see Mintz et al., 1992).

To investigate the possible participation of different $\mathrm{P} 2 \mathrm{Y}$ receptors in the inhibition of HVACCs in DRG neurons, various $\mathrm{P} 2 \mathrm{Y}$ receptor agonists and antagonists were tested. Single concentrations of ATP $(0.1-1000 \mu \mathrm{M} ; n=5-6)$ caused a steady-state inhibition of $I_{\mathrm{Ca}}$ within the $2 \mathrm{~min}$ application time (for $30 \mu \mathrm{M}$ ATP, see Fig. $2 \mathrm{Bb}$ ). $I_{\mathrm{Ca}}$ was depressed maximally by $\sim 70 \%$ of the 
original amplitude; the concentration producing $\mathrm{IC}_{50}$ was 28.1 $\mu \mathrm{M}$. Cumulative application of increasing concentrations of ATP $(0.1-1000 \mu \mathrm{M})$ every $2 \mathrm{~min}$ resulted in a concentration-response curve similar to that obtained with the single-dose application protocol (Fig. $2 \mathrm{Ba}$ ); the $\mathrm{IC}_{50}$ value was $19.1 \mu \mathrm{M}$. Cumulative application of the $\mathrm{P}_{2} \mathrm{Y}_{1,12,13}$ receptor agonist $\mathrm{ADP}(0.1-1000$ $\mu \mathrm{M})$, concentration-dependently inhibited the calcium current with an $\mathrm{IC}_{50}$ value of $664 \mathrm{~nm}$ (Fig. 2Ba), indicating that the potency of ADP was higher than that of ATP. It is noteworthy that $\mathrm{UTP}(0.001-100 \mu \mathrm{M})$ also inhibited $I_{\mathrm{Ca}}$ with an $\mathrm{IC}_{50}$ value of 103 nм (Fig. $2 \mathrm{Ba}$ ). In the following experiments, a 7 min superfusion with $\mathrm{P} 2 \mathrm{Y}$ receptor antagonists was followed by a 2 min application of ATP $(30 \mu \mathrm{M})$ (Fig. $2 \mathrm{Bb}$ ). The $\mathrm{P}_{2} \mathrm{Y}_{1}$ receptor-selective antagonists PPADS $(30 \mu \mathrm{M})$ and MRS 2179 greatly reduced the ATP-induced inhibition of HVACCs (Fig. $2 \mathrm{Bb}$ ).

\section{Colocalization of $\mathrm{P} 2 \mathrm{X}_{3}$ and $\mathrm{P} 2 \mathrm{Y}_{1}$ receptor subtypes on small- diameter DRG neurons}

To demonstrate the functional coexistence of $\mathrm{P} 2 \mathrm{X}$ and $\mathrm{P} 2 \mathrm{Y}$ receptors on the same DRG neuron, a NaCl-containing extracellular solution was used instead of the usual medium in which all $\mathrm{Na}^{+}$was completely replaced by TEA ${ }^{+}$. Under these conditions, voltage-dependent $\mathrm{K}^{+}$and $\mathrm{Na}^{+}$channels were inhibited by TEA $(20 \mathrm{mM})$ and TTX $(0.5 \mu \mathrm{M})$, respectively. A single depolarizing step from -90 to $-10 \mathrm{mV}$ evoked a current that included two components attributable to sodium and calcium ions flowing through the voltage-dependent TTX-insensitive $\mathrm{Na}^{+}$channels (Roy and Narahashi, 1992) and HVACCs, respectively (Fig. 3Aa). Omission of $\mathrm{Ca}^{2+}$ from the extracellular solution (no added $\mathrm{Ca}^{2+}$ plus $1 \mathrm{~mm}$ EGTA) inhibited the late component of the current response by $57.6 \pm 6.8 \%(n=7 ; p<0.05)$ (Fig. 3Aa). Application of ATP $(30 \mu \mathrm{M})$ caused a rapidly desensitizing inward current that was produced conceivably via activation of $\mathrm{P}_{2} \mathrm{X}_{3}$ receptor channels. ATP, given for $2 \mathrm{~min}$, failed to affect the early component of the current response to depolarizing stimuli in a statistically significant manner $(0.1 \pm 5.6 \% ; n=8 ; p>0.05)$ but inhibited its late component $(19.2 \pm 3.3 \% ; n=8 ; p<0.05)$. Both the effects of a $\mathrm{Ca}^{2+}$-free medium and of ATP $(30 \mu \mathrm{M})$ were reversed on washout with normal external medium. Subtraction of the currents recorded in the nominal absence of $\mathrm{Ca}^{2+}$ from the control currents as well as from those recorded in the presence of ATP $(30 \mu \mathrm{M})$ demonstrated the inhibition of $I_{\mathrm{Ca}}$ by ATP (Fig. $3 A b)$.

Immunofluorescence in combination with confocal laser scanning microscopy confirmed the colocalization of the $\mathrm{P} 2 \mathrm{X}_{3}$ and $\mathrm{P}_{2} \mathrm{Y}_{1}$ receptor subtypes on the cell bodies of VR1immunoreactive cells (Fig. 3B). Almost every small-diameter neuron was immunoreactive for VR1 receptors $(97.8 \pm 1.3 \%$; $n=4)$. A costaining for $\mathrm{P}_{2} \mathrm{Y}_{1}, \mathrm{P}_{2} \mathrm{X}_{3}$, and VR1 receptors was observed in $82.5 \pm 3.1 \%(n=4)$ of this neuronal population $\left(\mathrm{P}_{2} \mathrm{X}_{3}\right.$ and $\mathrm{P} 2 \mathrm{Y}_{1}$ receptor colocalization) (Ruan and Burnstock, 2003).

\section{Inhibition of the $\mathrm{N}$-type $\mathrm{Ca}^{2+}$ current by $\mathrm{G} \boldsymbol{\beta} \gamma$}

The above experiments demonstrate that, in an extracellular solution containing both TEA and TTX to block voltage-dependent $\mathrm{K}^{+}$and $\mathrm{Na}^{+}$channels, respectively, the $\mathrm{P} 2 \mathrm{X}_{3}$ receptor-mediated inward current had already been desensitized completely at the time point when ATP still caused a clear depression of $I_{\mathrm{Ca}}$. Hence, the direct participation of an endogenous $\mathrm{P} 2 \mathrm{X}$ receptor in the inhibition of the N-type $\mathrm{Ca}^{2+}$ current is most unlikely. The indirect inhibition of the $\mathrm{Ca}^{2+}$ current [e.g., by $\mathrm{Ca}^{2+}$ entering into the cell via $\mathrm{P}_{2} \mathrm{X}_{3}$ receptor channels and, thereby, evoking $\mathrm{Ca}^{2+}$-dependent inactiva-

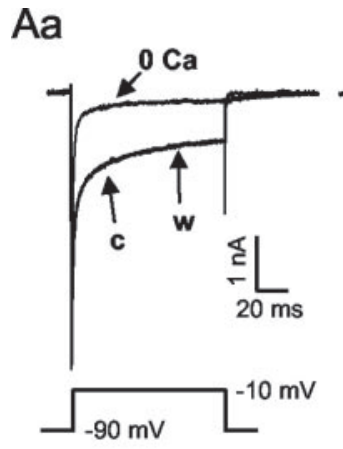

$\mathrm{B}$

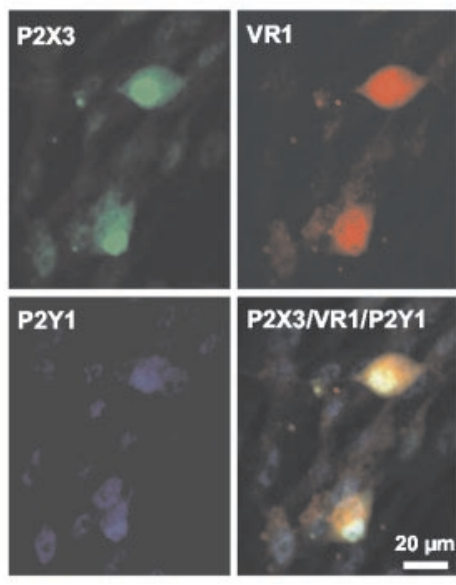

ATP $30 \mu \mathrm{M}$

$\overline{5 s}$

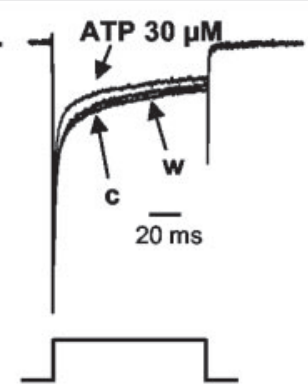

$\mathrm{Ab}$

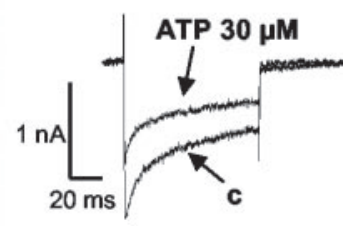

Figure 3. Functional and immunhistochemical evidence for the coexistence of $P 2 X_{3}, V R 1$, and $P 2 Y_{1}$ receptors on the same DRG cell population. $A a$, Calcium currents and TTX-insensitive sodium currents were recorded in rat DRGs using the whole-cell configuration of the patchclamp technique. A NaCl- and TTX-containing extracellular solution (see Materials and Methods) was used. Voltage steps were made from a holding potential of -90 to $-10 \mathrm{mV}$ every 20 sec to induce inward currents. After three control currents (c), $\mathrm{Ca}^{2+}$-free extracellular solution (no added $\mathrm{Ca}^{2+}$ plus $1 \mathrm{~mm}$ EGTA) was superfused for $2 \mathrm{~min}(0 \mathrm{Ca})$ and then was washed out (w). Subsequently, ATP $(30 \mu \mathrm{m})$ induced an inward current that recovered within seconds to baseline but continued to inhibit the depolarization-evoked currents. This effect was washed out within $1 \mathrm{~min}(\mathrm{w})$. $A b$, When $I_{\mathrm{Ca}}$ was calculated by subtraction of the currents recorded in the absence of $\mathrm{Ca}^{2+}$ from the control currents as well as from those recorded in the presence of ATP $(30 \mu \mathrm{M})$, ATP was found to cause inhibition. Note the different current calibrations in $A a$ and $A b$. $B$, Triple immunofluorescence for $P 2 X_{3}, V R 1$, and $P 2 Y_{1}$ receptors of rat DRG neurons investigated by means of a laser scanning confocal microscope. Images are of fluorescence for $\mathrm{P} 2 \mathrm{X}_{3}$ (green Cy2 immunofluorescence), VR1 (red CY3-immunofluorescence), and $P 2 Y_{1}$ (blue Cy5 immunofluorescence) receptor subtypes. Colocalization of $P 2 X_{3}, V R 1$, and $P 2 Y_{1}$ receptors is shown.

tion of $I_{\mathrm{Ca}}$ (Budde et al., 2002)] could be excluded; ATP depressed $I_{\mathrm{Ca}}$ despite failing to alter the holding current when the external medium contained $\mathrm{Cs}^{+}$in the place of $\mathrm{Na}^{+}$.

To assess the possible involvement of different transduction pathways in the inhibition of $I_{\mathrm{Ca}}$ by G-protein-coupled P2Y receptors, a strongly depolarizing prepulse to $+120 \mathrm{mV}$ (20 msec duration), known to convert channels inhibited through the membrane-delimited pathway from the "willing" to the "reluctant" mode (Bean, 1989), was applied. This prepulse markedly counteracted the effect of ATP (Fig. $4 A b, B a, B b$ ). In additional experiments, instead of GTP, GDP- $\beta$-S $(0.3 \mathrm{~mm})$, an inhibitor of G-protein-dependent processes (Sternweis and Pang, 1990), was added to the standard pipette solution. Ten minutes after establishing whole-cell configuration with a GDP- $\beta$-S-containing micropipette, ATP $(100 \mu \mathrm{M})$ failed to inhibit $I_{\mathrm{Ca}}$ (Fig. $\left.4 A c, B a, B b\right)$. 
Aa

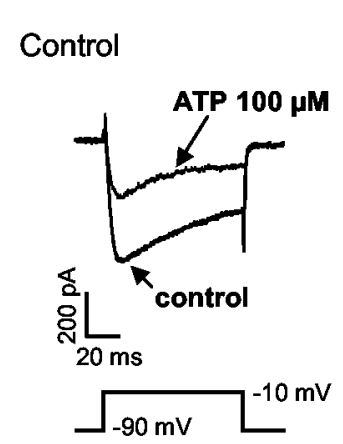

\section{GDP- $\beta-S$}

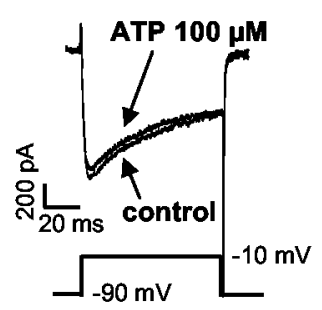

$\mathrm{Ba}$

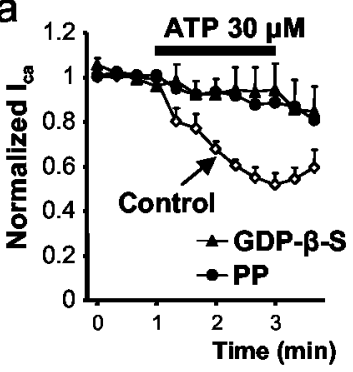

b

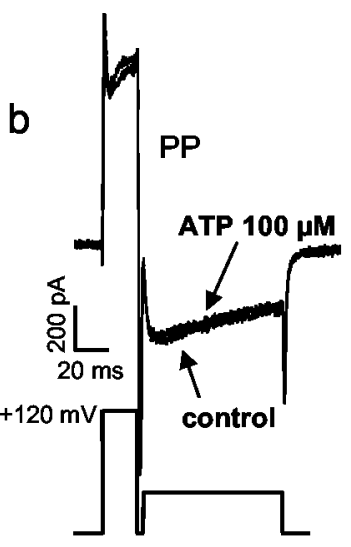

d EGTA $1.1 \mathrm{mM}$

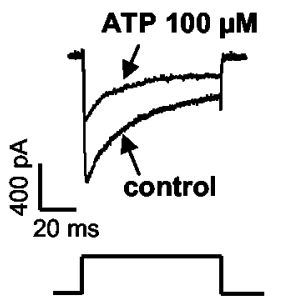

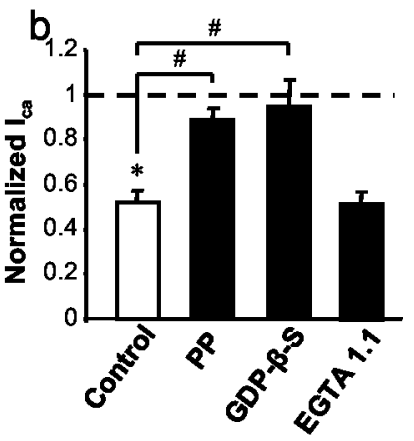

Figure 4. The possible transduction pathway of the ATP-induced inhibition of HVACCs. Calcium currents were recorded in rat DRGs using the whole-cell configuration of the patch-clamp technique. Voltage steps were made from a holding potential of -90 to $-10 \mathrm{mV}$ every $20 \mathrm{sec}$ to induce inward currents. $A$, Representative tracings. $A a$, HVACC currents before (control) and during the application of ATP $(100 \mu \mathrm{M})$ for $2 \mathrm{~min}$. A standard pipette solution containing GTP $(0.3 \mathrm{~mm} ; n=6)$ was used. $A b$, The regular pulse preceded by a strongly depolarizing prepulse (PP) to $+120 \mathrm{mV}$ abolished the inhibitory effect of ATP $(100 \mu \mathrm{m} ; n=5)$. Ac, HVACC currents recorded with a pipette solution containing GDP- $\beta$-S $(0.3 \mathrm{~mm} ; n=7)$ instead of GTP. Ad, HVACC currents recorded with an intracellular solution containing $1.1 \mathrm{~mm}$ EGTA instead of the usual 11 $\mathrm{mm}(n=10) . B a$, Data were normalized to the first four points of each series of experiments and expressed as means $\pm S E M . I_{C a}$ before, during, and after superfusion of ATP $(30 \mu \mathrm{M})$, recorded with a pipette solution containing GTP $(0.3 \mathrm{~mm}$; control) or GDP- $\beta-S(0.3 \mathrm{~mm})$ is shown; the effect of a strongly depolarizing prepulse (PP) on the ATP-induced inhibition is shown. $B b$, Summary data. Bars are means \pm SEM expressed as a percentage of the four control currents before drug application. The number of experiments is indicated in $A .{ }^{*} p<0.05$, statistically significant difference from the average of the first four currents measured before the application of ATP; $\# p<0.05$, statistically significant difference between the indicated bars.

Finally, the reduction of the internal EGTA from 11 to $1.1 \mathrm{~mm}$, which results in less efficient buffering of the intracellular-free $\mathrm{Ca}^{2+}$ concentration, did not change the ATP-induced inhibition of $I_{\mathrm{Ca}}$ (Fig. $4 A d, B b$ ). These findings indicate that after the activation of the G-protein-coupled P2Y receptors by ATP, the $\beta \gamma$ subunit of the G-protein, directly inhibits the N-type VACCs through a membrane-delimited pathway.

Inhibition of depolarization-induced increase of intracellular $\mathrm{Ca}^{2+}$ by $\mathrm{P} 2 \mathrm{Y}$ receptors

All DRG neurons used for $\mathrm{Ca}^{2+}$ imaging were labeled with $\mathrm{IB}_{4}$ and had diameters $(20-35 \mu \mathrm{m})$ similar to those used for patchclamp experiments. The application of a $50 \mathrm{mM} \mathrm{K}^{+}$-containing medium for $2 \mathrm{sec}$, as well as the application of ATP $(30 \mu \mathrm{M})$, $\alpha, \beta$-meATP $(30 \mu \mathrm{M})$, or ADP- $\beta$-S $(30 \mu \mathrm{M})$ for $10 \mathrm{sec}$ each, every $10 \mathrm{~min}$, caused reproducible increases of intracellular $\mathrm{Ca}^{2+}$ $\left(\left[\mathrm{Ca}^{2+}\right]_{\mathrm{i}}\right)$. Apparently, a high external $\mathrm{K}^{+}$concentration depolarizes the neuronal membrane, leads to the opening of VACCs, and allows $\mathrm{Ca}^{2+}$ to enter the cell. In support of this assumption, omission of $\mathrm{Ca}^{2+}$ from the bath solution for $3 \mathrm{~min}$ abolished the high $\mathrm{K}^{+}$-induced increase in $\left[\mathrm{Ca}^{2+}\right]_{\mathrm{i}}(99.4 \pm 0.3 \%$ inhibition; $n=16 ; p<0.05)$ identifying the extracellular solution as the sole source of $\left[\mathrm{Ca}^{2+}\right]_{\mathrm{i}}$. In contrast, superfusion with the $\mathrm{Ca}^{2+}$-free medium for $3 \mathrm{~min}$ only approximately halved the response to $\operatorname{ATP}(30 \mu \mathrm{M} ; 54.3 \pm 8.7 \%$ inhibition; $n=15 ; p<0.05)$, suggesting that ATP leads to the entry of $\mathrm{Ca}^{2+}$ via $\mathrm{P} 2 \mathrm{X}$ receptor channels and, in addition, releases $\mathrm{Ca}^{2+}$ from intracellular pools via $\mathrm{P} 2 \mathrm{Y}$ receptor activation (Ralevic and Burnstock, 1998). ADP- $\beta$-S (30 $\mu \mathrm{M})$, despite its assumed selectivity for $\mathrm{P}_{2} \mathrm{Y}_{1,12,13}$ receptors, exhibited, at the rather high concentration used, a considerable residual activity on $\mathrm{P} 2 \mathrm{X}$ receptors, because the $\mathrm{ADP}-\beta$-S-induced $\left[\mathrm{Ca}^{2+}\right]_{\mathrm{i}}$ transients were partially dependent on external $\mathrm{Ca}^{2+}$ (52.5 $\pm 14.0 \%$ inhibition in a $\mathrm{Ca}^{2+}$-free medium; $n=9 ; p<$ $0.05)$. In contrast, $\alpha, \beta$-meATP $(30 \mu \mathrm{M})$ induced $\left[\mathrm{Ca}^{2+}\right]_{\mathrm{i}}$ transients that were absolutely dependent on external $\mathrm{Ca}^{2+}(97.6 \pm$ $0.6 \%$ inhibition in a $\mathrm{Ca}^{2+}$-free medium; $n=9 ; p<0.05$ ), identifying the site of agonist action as the $\mathrm{P} 2 \mathrm{X}_{3}$ receptor channel.

$\operatorname{ATP}(30 \mu \mathrm{M})$ was applied $60 \mathrm{sec}$ before, during, and after high $\mathrm{K}^{+}$superfusion for $90 \mathrm{sec}$ in total (Fig. $5 \mathrm{Aa}$ ). The last response to $\mathrm{K}^{+}$before the application of ATP was considered to be $100 \%$. ATP $(30 \mu \mathrm{M})$ raised $\left[\mathrm{Ca}^{2+}\right]_{\mathrm{i}}$ exemplified by the corresponding change of the fluorescence ratio and, at the same time, depressed the effect of the high $\mathrm{K}^{+}$stimulus (Fig. 5Aa,B; Table 1). Both effects depended on the concentration of ATP used $(0.3,3,30$, or $300 \mu \mathrm{M}$ ), with a maximum at $30 \mu \mathrm{M}$ ATP (Table 1). PPADS (30 $\mu \mathrm{M})$ applied for $10 \mathrm{~min}$ before the first $\mathrm{K}^{+}$stimulation and throughout reduced the increase of $\left[\mathrm{Ca}^{2+}\right]_{\mathrm{i}}$ by ATP and, in addition, reversed the ATP-induced inhibition of the high $\mathrm{K}^{+}$effect (Table 1). ADP- $\beta$-S (30 $\mu \mathrm{M})$ increased the fluorescence ratio and simultaneously inhibited the response to $\mathrm{K}^{+}$, thereby acting in a manner indistinguishable from ATP itself (Fig. 5Ab, $B$; Table 1). The effect of ADP- $\beta$-S was antagonized fully by the selective P2Y receptor antagonist MRS $2179(30 \mu \mathrm{M})$ (Table 1). Finally, $\alpha, \beta$ meATP $(30 \mu \mathrm{M})$, an agonist at $\mathrm{P}_{2} \mathrm{X}_{1,3}$ receptors, increased $\left[\mathrm{Ca}^{2+}\right]_{\mathrm{i}}$ and potentiated the response to high $\mathrm{K}^{+}$(Fig. $5 A c, B$; Table 1). Both effects were concentration dependent and seemed to be caused by the activation of $\mathrm{P} 2 \mathrm{X}_{3}$ receptors, because the $\mathrm{P}_{2} \mathrm{X}_{1,3}$ receptor-selective TNP-ATP $(30 \mu \mathrm{M})$ was clearly antagonistic (Table 1).

\section{Inhibition of spinal nociceptive transmission by P2Y receptors}

Low- and high-intensity electrical stimuli were applied to the dorsal root of the hemisected spinal cord preparation. The lowintensity stimulation evoked an initial monosynaptic compound action potential (MSR), superimposed on a polysynaptic population EPSP. These two potentials were mediated by A-fibers. The high-intensity stimuli evoked prolonged, presumably both Aand C-fiber-mediated, polysynaptic EPSPs. Low-intensity EPSPs were facilitated by ADP- $\beta$-S at $1 \mu \mathrm{M}$, unaltered at $10 \mu \mathrm{M}$, and 


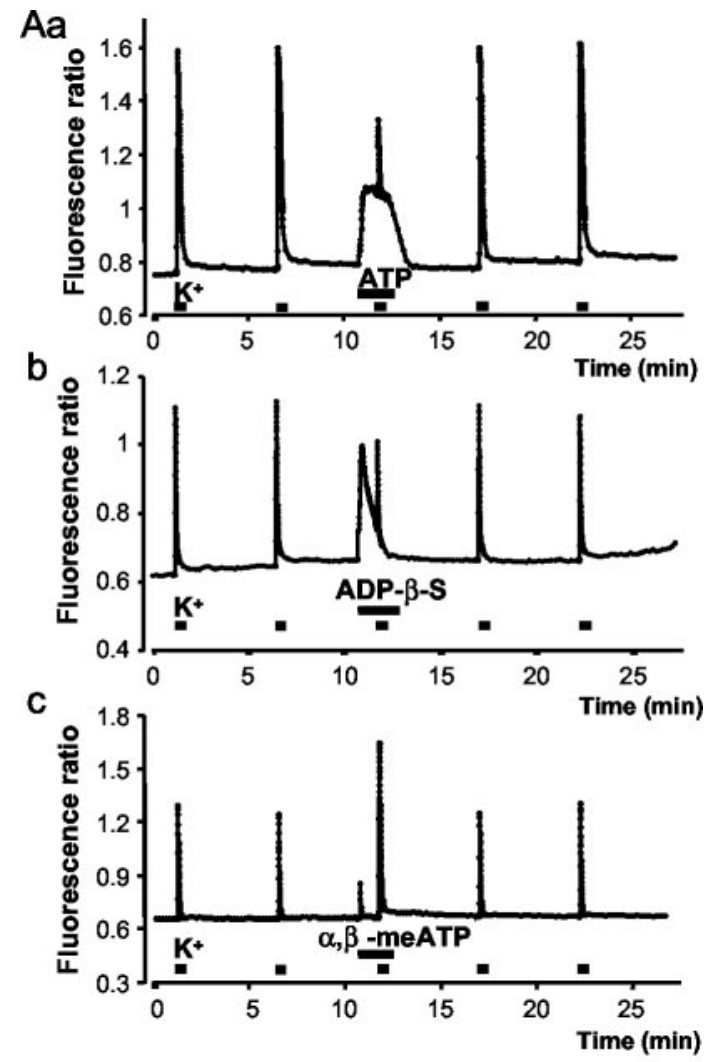

B

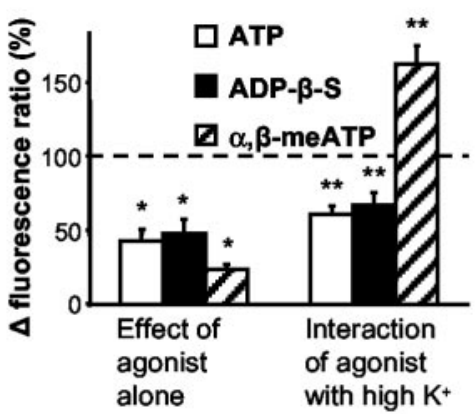

Figure 5. Dual effect of $P 2 Y$ receptor agonists on the intracellular calcium concentration of rat DRG neurons by $P 2 Y$ receptor agonists. Cells were loaded with the fluorescent indicator fura-2 acetoxymethyl ester $(1 \mu \mathrm{m})$. The fluorescence ratio $(340 / 380 \mathrm{~nm})$ was taken as a measure of the cytosolic free $\mathrm{Ca}^{2+}$ concentration $\left(\left[\mathrm{Ca}^{2+}\right]_{\mathrm{i}}\right)$. DRG neurons were depolarized by a 50 $\mathrm{mm} \mathrm{K}^{+}$-containing extracellular medium for $2 \mathrm{sec}$. ATP, ADP- $\beta$-S, or $\alpha, \beta$-meATP (30 $\mu$ m each) was applied 60 sec before, during, and after high $\mathrm{K}^{+}$superfusion for 90 sec in total. $A$, Representative experiments. Constant increase by ATP $(A a)$ and transient increases by ADP- $\beta-S(A b)$ and especially by $\alpha, \beta$-meATP $(A C)$ of basal $\left[\mathrm{Ca}^{2+}\right]_{\mathrm{i}}$ is shown. Inhibition by ATP $(A a)$ and ADP$\beta$-S $(A b)$ but potentiation by $\alpha, \beta$-meATP $(A c)$ of the high $\mathrm{K}^{+}$-induced $\left[\mathrm{Ca}^{2+}\right]_{\mathrm{i}}$ transients is shown. $B$, Percentage changes of the $\Delta$ fluorescence ratio by ATP, ADP- $\beta$-S, and $\alpha, \beta$-meATP when the second response to high $\mathrm{K}^{+}$before superfusion with drugs was considered to be $100 \%$. Data are means \pm SEM of $15-38$ experiments. ${ }^{*} p<0.05$, statistically significant difference from $0 \%$ (first set of columns); ${ }^{* *} p<0.05$, statistically significant difference from $100 \%$ (second set of columns).

inhibited at $100 \mu \mathrm{M}$ (Fig. 6Ab). In contrast, high-intensity EPSPs were markedly depressed by ADP- $\beta$-S at $100 \mu \mathrm{M}$, with a threshold of inhibition at $10 \mu \mathrm{M}$ of the agonist (Fig. $6 A a, A b$ ). The inhibitory effect of ADP- $\beta$-S $(100 \mu \mathrm{M})$ of both low- and high-intensity EPSPs was completely reversed after its washout. The MSR was not significantly affected by ADP- $\beta$-S at any of the concentrations tested (Fig. 6Ab).

The following experiments were designed to identify the indi- vidual $\mathrm{P} 2 \mathrm{Y}$ receptor(s) involved in the ADP- $\beta$-S-induced inhibition of high-intensity EPSPs. Neither the $\mathrm{P} 2 \mathrm{Y}_{1}$ receptorpreferential antagonist PPADS $(30 \mu \mathrm{M})(\mathrm{ADP}-\beta-\mathrm{S}, 51.8 \pm 6.4 \%$; ADP- $\beta$-S plus PPADS, $70.7 \pm 14.1 ; n=10$ each; $p>0.05)$ nor the $\mathrm{P} 2 \mathrm{Y}_{12,13}$ receptor-selective antagonist AR-C69931MX (1 $\mu \mathrm{M}$; a concentration about three orders of magnitude higher than its $\mathrm{IC}_{50}$ value against $\mathrm{ADP}$-induced platelet aggregation) (Ingall et al., 1999) antagonized the effect of ADP- $\beta$-S (100 $\mu \mathrm{M})(\mathrm{ADP}-\beta-\mathrm{S}$, $56.2 \pm 18.5 \%$; ADP- $\beta$-S plus AR-C69931MX, $56.0 \pm 14.1 \%$; $n=$ 7 each; $p>0.05)$. The $\mathrm{P}_{2} \mathrm{Y}_{1}$-selective antagonist $\mathrm{MRS} 2179(1,10$, and $30 \mu \mathrm{M}$, at the highest concentration $\sim 100$ times its $K_{\mathrm{i}}$ value at the $\mathrm{P}_{2} \mathrm{Y}_{1}$ receptor) (Boyer et al., 1998) produced a substantial inhibition of EPSPs on its own (data not shown). Therefore, this antagonist could not be used to investigate the involvement of $\mathrm{P}_{2} \mathrm{Y}_{1}$ receptors. Finally, the nonselective $\mathrm{P} 2$ receptor antagonist suramin $(30 \mu \mathrm{M})$ also failed to antagonize the inhibitory effect of ADP- $\beta$-S $(100 \mu \mathrm{M})(\mathrm{ADP}-\beta-\mathrm{S}, 57.0 \pm 6.6 \%$; ADP- $\beta$-S plus suramin, $48.1 \pm 11.0 \% ; n=5$ each; $p>0.05)$. It is interesting to note that the $\mathrm{P}_{2} \mathrm{Y}_{2,4,6}$ receptor agonist UTP did not change the high-intensity EPSPs at lower concentrations (0.01-0.1 $\mu \mathrm{M} ; n=$ 5; data not shown) but facilitated them at the higher concentration of $1 \mu \mathrm{M}(137.3 \pm 8.6 \% ; n=5 ; p<0.05)$. Finally, PPADS $(30$ $\mu \mathrm{M})$ slightly increased the high-intensity EPSP when given alone $(137.3 \pm 8.6 \% ; n=5 ; p<0.05)$, whereas both AR-C69931MX ( 1 $\mu \mathrm{M})$ and suramin $(30 \mu \mathrm{M})$ had no effect (data not shown).

\section{ADP- $\beta-S$ is antinociceptive in the tail-flick test after intrathecal application}

To find out whether ADP- $\beta$-S exerts antinociceptive effects in vivo, the compound was tested in the tail-flick assay after intrathecal administration. ADP- $\beta$-S $(1,4.6,10$, and $100 \mathrm{nmol} / \mathrm{ani}$ $\mathrm{mal}$ ) increased the nociceptive threshold in response to an acute thermal stimulus, because tail-withdrawal latencies were prolonged in a dose-dependent manner (Fig. 6B). Because 10 min after drug application ether anesthesia still slightly interfered with withdrawal latencies (Fig. $6 \mathrm{~B}, 0.9 \% \mathrm{NaCl}$ ), the $\mathrm{ED}_{50}$ value was calculated at $20 \mathrm{~min}$ after application. Vehicle $(0.9 \% \mathrm{NaCl})$ injection exerted no effect on nociceptive thresholds in control animals. The $\mathrm{ED}_{50}$ value of the acute antinociceptive effect of ADP$\beta$-S amounted to $16.1 \mathrm{nmol} /$ animal. Intrathecal ADP- $\beta$-S (100 nmol/animal; $65.2 \pm 4.9 \%$ of the MPE; $n=10$ ) was not antagonized by pretreatment with intrathecal PPADS (30 nmol/animal; $74.1 \pm 10.0 \% \mathrm{MPE} ; n=10 ; p>0.05)$. In PPADS $(30 \mathrm{nmol} /$ animal, intrathecal) control experiments, only a negligible effect on withdrawal latencies was observed $(19.1 \pm 5.5 \% \mathrm{MPE} ; n=10$; $p<0.05)$. PPADS at $10 \mathrm{nmol} /$ animal also did not antagonize the antinociceptive effect of ADP- $\beta$-S (100 nmol/animal), although this concentration of intrathecal PPADS has been shown to antagonize the decrease by $\alpha, \beta$-meATP of the thermal nociceptive threshold (Tsuda et al., 1999).

\section{Discussion}

The main finding here is that $\mathrm{P} 2 \mathrm{Y}_{1}$ receptor activation inhibits VACCs and the subsequent increase of the intracellular $\mathrm{Ca}^{2+}$ concentration in small nociceptive DRG neurons of rats. It has been suggested repeatedly that the properties of the DRG cell bodies and their terminals are, in many respects, similar (Belmonte and Gallego, 1983). Hence, it is assumed that P2Y receptors interfere with excitatory synaptic transmission from the central terminals of sensory neurons onto spinal cord neurons. In accordance with this idea, ADP- $\beta$-S, a P2Y $\mathrm{Y}_{1,12,13}$ receptorpreferential agonist inhibited C-fiber-mediated polysynaptic 
Table 1. Increase of the intracellular free $\mathrm{Ca}^{2+}$ concentration by $\mathrm{P} 2$ receptor agonists when given alone and inhibition by the same agonists of the high $\mathrm{K}^{+}$-induced entry of $\mathrm{Ca}^{2+}$ into the cell, and interaction with $\mathrm{P} 2$ receptor antagonists.

\begin{tabular}{|c|c|c|c|c|c|c|}
\hline Agonist & $\mu \mathrm{M}$ & Antagonist & $\mu \mathrm{M}$ & $\begin{array}{l}\text { Percentage } \\
(\%) \text { increase } \\
\text { of }\left[\mathrm{Ca}^{2+}\right]_{\mathrm{i}}\end{array}$ & $\begin{array}{l}\text { Percentage (\%) inhibition } \\
\text { of the high } \mathrm{K}^{+} \text {-induced } \\
{\left[\mathrm{Ca}^{2+}\right]_{\mathrm{i}} \text { elevation }}\end{array}$ & Number \\
\hline \multirow[t]{5}{*}{ ATP } & 0.3 & & & $7.8 \pm 1.1^{a}$ & $-14.9 \pm 6.2$ & 25 \\
\hline & 3 & & & $16.6 \pm 3.1^{a}$ & $20.5 \pm 5.1$ & 12 \\
\hline & 30 & & & $42.5 \pm 8.2^{a}$ & $38.9 \pm 5.4^{b}$ & 38 \\
\hline & 300 & & & $55.1 \pm 10.1^{a}$ & $30.1 \pm 4.3^{b}$ & 39 \\
\hline & 30 & PPADS & & $18.1 \pm 4.9^{a, c}$ & $-1.4 \pm 6.0^{c}$ & 27 \\
\hline \multirow[t]{2}{*}{$A D P-\beta-S$} & 30 & & & $47.9 \pm 9.4^{a}$ & $32.8 \pm 8.6^{a}$ & 32 \\
\hline & 30 & MRS 2179 & 30 & $14.9 \pm 6.3^{a, c}$ & $-15.6 \pm 5.0^{c}$ & 11 \\
\hline \multirow[t]{4}{*}{$\alpha, \beta$-meATP } & 3 & & & $19.7 \pm 3.8^{a}$ & $-4.4 \pm 5.2$ & 18 \\
\hline & 30 & & & $23.6 \pm 3.6^{a}$ & $-62.6 \pm 12.7^{b}$ & 15 \\
\hline & 300 & & & $37.8 \pm 8.6^{a}$ & $-125.4 \pm 18.2^{b}$ & 16 \\
\hline & 30 & TNP-ATP & 0.01 & $1.3 \pm 0.2^{c}$ & $37.9 \pm 5.5^{a, c}$ & 16 \\
\hline
\end{tabular}

${ }^{a} p<0.05$; significant difference from $0 \%$

${ }^{b} p<0.05$; significant difference from $100 \%$.

${ }^{c} p<0.05$; significant difference from the effect of the respective agonist in the absence of the respective antagonist.

EPSPs in the rat spinal cord and thereby increased the nociceptive threshold when pain-induced behavior was measured with the tail-flick test.

A subtype of ionotropic ATP receptors, the $\mathrm{P} 2 \mathrm{X}_{3}$ receptor (Chen et al., 1995; Lewis et al., 1995) is expressed with considerable selectivity by small-diameter, nonpeptidergic DRG neurons specifically binding the isolectin $\mathrm{B}_{4}$ (Chizh and Illes, 2001). Immunocytochemistry studies indicate that these neurons project to lamina II of the dorsal horn (Vulchanova et al., 1998). There is relatively high level of colocalization of $\mathrm{P}_{2} \mathrm{X}_{3}$ receptor immunoreactivity with the vanilloid VR1 receptor (Guo et al., 1999), which confers sensitivity to noxious heat (Caterina et al., 1997).

In the present patch-clamp study, when calcium was the sole charge carrier, ramp-like depolarizations evoked both LVACC and HVACC currents of rat DRG neurons. The HVACC current was preferentially depressed by the endogenous $\mathrm{P} 2$ receptor agonist ATP. In addition to the characteristic voltage at which they are activated and their differing single-channel properties, selective antagonists are known to block each channel type $(\mathrm{N}$, $\omega$-CTX; P/Q, $\omega$-Aga). We found that HVACC current responses to depolarizing voltage steps were blocked by $\omega$-CTX but not by $\omega$-Aga, thereby identifying the current as belonging to the $\mathrm{N}$ type but not to the P/Q type (but see Mintz et al., 1992). Moreover, the application of ATP in the presence of $\omega$-CTX did not cause any additional depression, supposedly because only the N-type current was sensitive to the inhibitory action of ATP.

The next series of experiments were designed to find out which of the eight known mammalian P2Y receptors is involved in the VACC inhibition. Interaction between ATP and the P2Y receptor-selective antagonists MRS 2179 and PPADS (von Kugelgen and Wetter, 2000) identified the blockade of VACCs as a $\mathrm{P}_{2} \mathrm{Y}_{1}$ receptor-function. In situ hybridization studies indicated a limited colocalization of $\mathrm{mRNA}$ for $\mathrm{P} 2 \mathrm{Y}_{1}$ and VR1 receptors on small-diameter DRG neurons, whereas $\mathrm{PY}_{2}$ and VR1 receptor mRNA colocalized to a much larger extent (Moriyama et al., 2003). In contrast, we demonstrated the coexpression of $\mathrm{P} 2 \mathrm{X}_{3}$, $\mathrm{P}_{2} \mathrm{Y}_{1}$, and VR1 receptor immunopositivities in $\sim 80 \%$ of smalldiameter DRG cells. A mismatch between the nucleic acid message and its expression at the protein level is a possible explanation for this discrepancy. In addition, $\mathrm{P}_{2} \mathrm{X}_{3}$ (induction of a rapidly desensitizing inward current) and $\mathrm{P}_{2} \mathrm{Y}_{1}$ receptor (inhibition of VACCs) functions were also found to be confined to identical DRG neurons. The blockade of $I_{\mathrm{Ca}}$ by both ADP and
UTP conformed with the presence of $\mathrm{P} 2 \mathrm{Y}_{1}$ and $\mathrm{P} 2 \mathrm{Y}_{2}$ receptors on the same DRG neuron; both receptors were reported to lead to the phosphorylation of VR1 receptor channels and thereby increase their conductance (Tominaga et al., 2001; Moriyama et al., 2003). This may cause thermal hypersensitivity and partly counteract the antinociception induced by the blockade of $I_{\mathrm{Ca}(\mathrm{N})}$, as proved for $\mathrm{P}_{2} \mathrm{Y}_{2}$, but not for $\mathrm{P} 2 \mathrm{Y}_{1}$, receptors (Moriyama et al., 2003).

Previous studies in neurons have identified different G-protein-dependent pathways involved in the inhibition of $I_{\mathrm{Ca}(\mathrm{N})}$ (Hille, 1994). One mechanism may involve diffusible second messengers and the subsequent activation of protein kinases (Boehm et al., 1996). A second mechanism is membrane delimited and involves neurotransmitter receptors, G-proteins, and voltage-dependent calcium channels. A key role of the $G \beta \gamma$ rather than $\mathrm{G} \alpha$ subunits had been proposed (Herlitze et al., 1996). In the present experiments, ATP time- and concentrationdependently inhibited $\mathrm{Ca}^{2+}$ currents and shifted the currentvoltage curve to the right, which are characteristic reactions after stimulation of G-protein-coupled receptors (Bean, 1989). Application of a strong depolarizing prepulse prevented ATP-induced inhibition of the $\mathrm{Ca}^{2+}$ current, indicating a G-protein-mediated mechanism of $\mathrm{Ca}^{2+}$ channel modulation (Bean, 1989). Intracellular dialysis with GDP- $\beta$-S, an inhibitor of G-proteindependent reactions (Sternweis and Pang, 1990), also prevented the action of ATP. A Ca ${ }^{2+}$-dependent inactivation of the $\mathrm{N}$-type $\mathrm{Ca}^{2+}$ channel (Budde et al., 2002) as a consequence of the P2Y receptor-induced increase of intracellular $\mathrm{Ca}^{2+}$ (Ralevic and Burnstock, 1998) could be excluded by the use of a lower concentration of EGTA in the pipette solution. Under these conditions, the calcium-buffering capacity of EGTA decreases and a $\mathrm{G} \alpha$ mediated triggering of the phospholipase $\mathrm{C}-\mathrm{IP}_{3}-\mathrm{Ca}^{2+}$ pathway could lead to a larger inhibition of $I_{\mathrm{Ca}(\mathrm{N})}$. However, this was apparently not the case, indicating the involvement of $\mathrm{G} \beta \gamma$ rather than $\mathrm{G} \alpha$ in this process.

In experiments directly measuring $\left[\mathrm{Ca}^{2+}\right]_{\mathrm{i}}$ by means of fura- 2 and $\mathrm{Ca}^{2+}$ imaging setup, the nonselective $\mathrm{P} 2$ receptor agonist ATP raised $\left[\mathrm{Ca}^{2+}\right]_{\mathrm{i}}$ when given alone and, at the same time, depressed the high $\mathrm{K}^{+}$-induced increase of $\left[\mathrm{Ca}^{2+}\right]_{\mathrm{i}}$. Whereas the former effect is attributable both to a $\mathrm{P}_{2} \mathrm{Y}_{1}(\mathrm{G} \alpha)$-mediated release of $\mathrm{Ca}^{2+}$ from its intracellular storage sites and the entry of $\mathrm{Ca}^{2+}$ via the $\mathrm{P} 2 \mathrm{X}_{3}$ receptor channel, the second effect seems to be a consequence of the membrane-delimited inhibition of $I_{\mathrm{Ca}(\mathrm{N})}$ by 


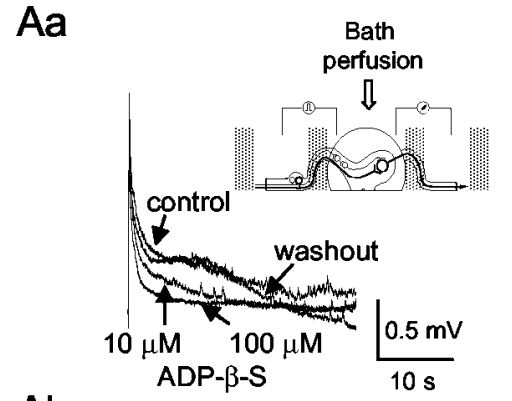

$\mathrm{Ab}$

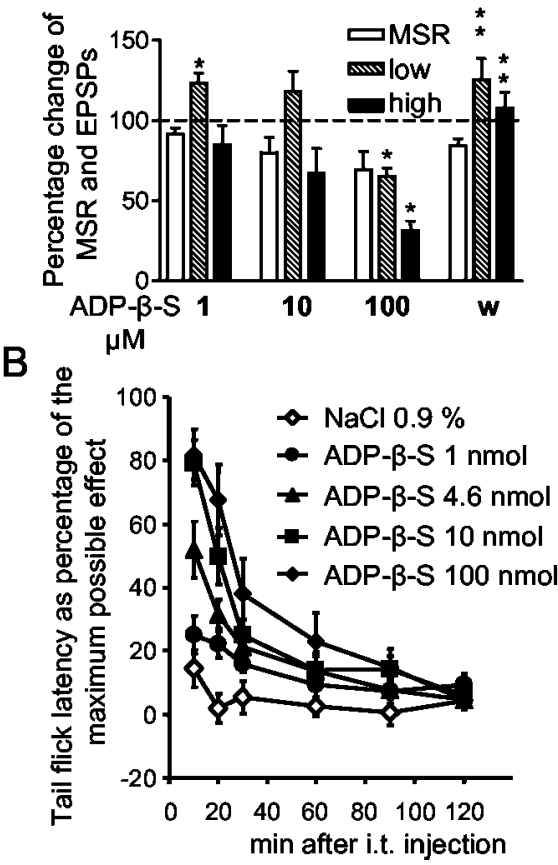

Figure 6. Modulation of segmental nociceptive spinal transmission by ADP- $\beta$-S in vitro and acute antinociceptive effect of ADP- $\beta$-S in vivo. Aa, Representative recordings showing highintensity-evoked A- and C-fiber-mediated polysynaptic EPSPs in the hemisected spinal cord preparation of a juvenile rat before (control) and after the cumulative addition of 1, 10, and 100 $\mu \mathrm{MADP}-\beta$-S to the perfusion medium, followed by washout. Each concentration of ADP- $\beta$-S as well as the control medium (washout) was superfused for $20-25$ min each. A scheme of the recording set-up is presented in the inset. The neuronal pathways involved in the monosynaptic and polysynaptic transmission are also shown. Ab, Summary data showing the effects of ADP$\beta$-S on dorsal root-evoked MSR and polysynaptic (low, low-intensity EPSP; high, high-intensity EPSP) dorsal root responses. Data are means \pm SEM of six experiments expressed as percentages of predrug control values. ${ }^{*} p<0.05$, statistically significant difference from control responses (100\%); ${ }^{* *} p<0.05$, statistically significant difference from the effect of the respective agonist concentration before washout. $B$, Measurement of tail-flick latency as a percentage of the maximum possible effect; dose-dependent antinociception caused by ADP- $\beta$-S. ADP- $\beta$-S was dissolved in $0.9 \% \mathrm{NaCl}$ and was injected intrathecally (i.t.) in the indicated doses per animal. The effect of an equivalent amount of solvent was also tested. Data are means \pm SEM of 10 experiments each.

$\mathrm{P}_{2} \mathrm{Y}_{1}(\mathrm{G} \beta \gamma)$ (Fig. 7). The use of preferential agonists (ADP- $\beta-\mathrm{S}$, $\mathrm{P}_{2} \mathrm{Y}_{1,12,13} ; \alpha, \beta$-meATP, $\left.\mathrm{P} 2 \mathrm{X}_{1,2,3}\right)$ and antagonists (MRS 2179, P2 $\mathrm{Y}_{1}$; TNP-ATP, $\mathrm{P} 2 \mathrm{X}_{1,3}$ ) supported these conclusions.

The preferential inhibition of C-fiber-induced population polysynaptic EPSPs in the hemisected spinal cord by ADP- $\beta-S$ localized the site of inhibition of synaptic responses to the dorsal horn of the spinal cord. $\mathrm{P} 2 \mathrm{X}_{3}$ receptors have been suggested to be expressed on the central terminals of $\mathrm{C}$-fibers innervating dorsal horn lamina II ( $\mathrm{Gu}$ and MacDermott, 1997). The activation of these receptors leads to an enhanced release of glutamate. Based

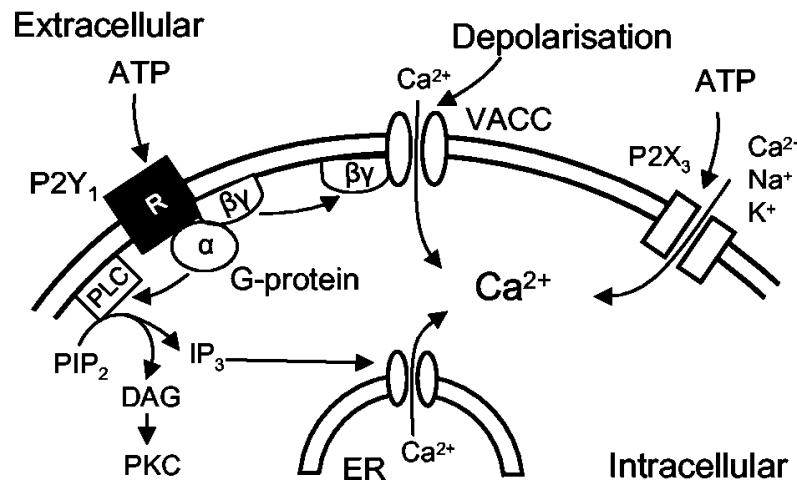

Figure 7. Schematic drawing demonstrating the multiple modulatory effects of ATP on intracellular $\mathrm{Ca}^{2+}$ in DRG neurons. ATP may activate $\mathrm{P} 2 \mathrm{X}_{3}$ receptor channels, thereby facilitating the entry of $\mathrm{Ca}^{2+}$ via these channels into the cell. Moreover, the activation of $\mathrm{P}_{2} \mathrm{Y}_{1}$ receptors may lead via the $G \alpha$ subunit to the generation of $\mathrm{IP}_{3}$ and the subsequent release of $\mathrm{Ca}^{2+}$ from the endoplasmatic reticulum. Finally, $\mathrm{P} 2 \mathrm{Y}$, receptors may also via $\mathrm{G} \beta \gamma$ close voltage-operated $\mathrm{Ca}^{2+}$ channels and thereby inhibit the passage of $\mathrm{Ca}^{2+}$ through the VACCs. Hence, the intracellular $\mathrm{Ca}^{2+}$ concentration may be modified by three simultaneous and partly opposing effects of ATP, two of which are algogenic (P2X,$P 2 Y_{1} / G \alpha$ ) and one antinociceptive $\left(P 2 Y_{1} /\right.$ $G \beta \gamma)$. PLC, phospholipase C; PIP 2 , phosphatidylinositol 4,5-bisphosphate; DAG, diacylglycerol; $\mathrm{ER}$, endoplasmatic reticulum.

on patch-clamp and $\mathrm{Ca}^{2+}$ imaging experiments in cultured DRG cells, we hypothesized that $\mathrm{P}_{2} \mathrm{Y}_{1}$ receptors situated on the central axon terminals of DRG neurons may cause analgesia by decreasing the release of glutamate. However, the $\mathrm{P}_{2} \mathrm{Y}_{1}$ receptorpreferential antagonist PPADS, the $\mathrm{P} 2 \mathrm{Y}_{12,13}$ receptor-selective antagonist AR-C69931MX (Barnard and Simon, 2001), and the nonselective $\mathrm{P} 2$ receptor antagonist suramin all failed to interact with the inhibitory effect of ADP- $\beta$-S in this system.

ATP has been reported to depress slow depolarization induced by repetitive dorsal root stimulation via $\mathrm{P} 2 \mathrm{Y}$ receptors in substantia gelatinosa neurons of the rat spinal cord (Yoshida et al., 2002). In agreement with our results, in the hemisected spinal cord, the broad-spectrum P2 receptor antagonist suramin did not interact with ATP in the experiments of Yoshida et al. (2002). An additional argument for the absence of $\mathrm{P} 2 \mathrm{Y}_{1}$ receptors on the central terminals of C-fibers is supplied by the failure of immunoreactivities for the vesicular glutamate transporter VGLUT2 (Bai et al., 2001) and P2Y receptors to colocalize in layer I-II of the spinal cord dorsal horn (W. Schröder, H. Franke, and P. Illes, unpublished observations). Hence, it is concluded that P2Y receptors, with a higher sensitivity for ADP than for ATP, are expressed on the central C-fiber terminals. However, this P2Y receptor does not conform in its ligand-binding characteristics with any of the presently known subtypes and still awaits structural determination.

As a final argument for the pharmacological significance of the supposedly presynaptically localized, and presently unclassified, inhibitory P2Y receptor, intrathecally applied ADP- $\beta$-S dose-dependently increased the tail-flick latency of rats. In perfect accordance with data obtained in the hemisected spinal cord, PPADS did not interfere with ADP- $\beta$-S, once again confirming the involvement of a $\mathrm{P} 2 \mathrm{Y}$ receptor distinct from $\mathrm{P} 2 \mathrm{Y}_{1}$. ADP- $\beta-\mathrm{S}$ rather than ADP itself was used in these experiments in view of the higher enzymatic stability of the ADP structural analog. Because the intrathecal injection of UTP and UDP has been shown to prolong thermal nociceptive latency in the tail-flick test (Okada et al., 2002), the ADP(ATP)-sensitive P2Y receptor de- 
scribed by us may be colocalized with a UDP(UTP)-sensitive P2Y receptor mediating spinal analgesia.

Hence, in conclusion, $\mathrm{P} 2 \mathrm{X}_{3}$ receptor activation by ATP may lead to increased firing of DRG cells and subsequently to increased release of the sensory transmitter glutamate from their central processes. An opposite effect on DRG neurons is also conceivable. $\mathrm{P} 2 \mathrm{Y}$ receptor activation by $\mathrm{ADP}$, which is generated by the enzymatic degradation of ATP, may decrease the release of glutamate onto secondary sensory neurons of the spinal cord and may thereby partly counterbalance the algogenic effect of ATP. Finally, we hypothesize that the $\mathrm{P} 2 \mathrm{Y}_{1}$ receptors found on immature cultured DRG neurons change their phenotype with development to a presently unclassified $\mathrm{P} 2 \mathrm{Y}$ receptor ( $\mathrm{P} 2 \mathrm{X}$ receptors) (Inokuchi and McLachlan, 1995).

\section{References}

Abbracchio MP, Burnstock G (1994) Purinoceptors: are there families of P2X and P2Y purinoceptors? Pharmacol Ther 64:445-475.

Abbracchio MP, Boeynaems JM, Barnard EA, Boyer JL, Kennedy C, MirasPortugal MT, King BF, Gachet C, Jacobson KA, Weisman GA, Burnstock G (2003) Characterization of the UDP-glucose receptor (re-named here the $\mathrm{P}_{2} \mathrm{Y}_{14}$ receptor) adds diversity to the $\mathrm{P} 2 \mathrm{Y}$ receptor family. Trends Pharmacol Sci 24:52-55.

Bai I, Xu H, Collins JF, Ghishan FK (2001) Molecular and functional analysis of a novel neuronal vesicular glutamate transporter. J Biol Chem 276:36764-36769.

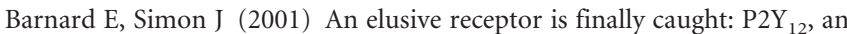
important drug target in platelets. Trends Pharmacol Sci 22:388-391.

Barry PH (1994) JPCalc, a software package for calculating liquid junction potential corrections in patch-clamp, intracellular, epithelial and bilayer measurements and for correcting junction potential measurements. J Neurosci Methods 51:107-116.

Bean BP (1989) Neurotransmitter inhibition of neuronal calcium currents by changes in channel voltage dependence. Nature 340:153-156.

Belmonte C, Gallego R (1983) Membrane properties of cat sensory neurones with chemoreceptor and baroreceptor endings. J Physiol (Lond) 342:603-614.

Boehm S (2003) P2Ys go neuronal: modulation of $\mathrm{Ca}^{2+}$ and $\mathrm{K}^{+}$channels by recombinant receptors. Br J Pharmacol 138:1-3.

Boehm S, Huck S, Freissmuth M (1996) Involvement of a phorbol esterinsensitive protein kinase $\mathrm{C}$ in the $\alpha_{2}$ adrenergic inhibition of voltagegated $\mathrm{Ca}^{2+}$ current in chick sympathetic neurons. J Neurosci 16:4596-4603.

Borvendeg SJ, Gerevich Z, Gillen C, Illes P (2003) P2Y receptor-mediated inhibition of voltage-dependent $\mathrm{Ca}^{2+}$ channels in rat dorsal root ganglion neurons. Synapse 47:159-161.

Boyer JL, Mohanram A, Camaioni E, Jacobson KA, Harden TK (1998) Competitive and selective antagonism of $\mathrm{P} 2 \mathrm{Y} 1$ receptors by $\mathrm{N}^{6}$-methyl 2'-deoxyadenosine 3', 5' -bisphosphate. Br J Pharmacol 124:1-3.

Budde T, Meuth S, Pape H-C (2002) Calcium-dependent inactivation of neuronal calcium channels. Nat Rev 3:873-883.

Burgard EC, Niforatos W, van Biesen T, Lynch KJ, Touma E, Metzger RE, Kowaluk EA, Jarvis MF (1999) P2X receptor-mediated ionic currents in dorsal root ganglion neurons. J Neurophysiol 82:1590-1598.

Caterina MJ, Schumacher MA, Tominaga M, Rosen TA, Levine JD, Julius D (1997) The capsaicin receptor: a heat-activated ion channel in the pain pathway. Nature 389:816-824.

Chen C-C, Akopian AN, Sivilotti L, Colquhoun D, Burnstock G, Wood JN (1995) A P2X purinoceptor expressed by a subset of sensory neurons. Nature 377:428-431.

Chizh BA, Illes P (2001) P2X receptors and nociception. Pharmacol Rev 53:553-568.

Communi D, Gonzalez NS, Detheux M, Brezillon S, Lannoy V, Parmentier M, Boeynaems JM (2001) Identification of a novel human ADP receptor coupled to $\mathrm{G}_{\mathrm{i}}$. J Biol Chem 276:41479-41485.

D'Amour FE, Smith DL (1941) A method for determining loss of pain sensation. J Pharmacol Exp Ther 72:74-79.

Diaz A, Dickenson AH (1997) Blockade of spinal N- and P-type, but not L-type, calcium channels inhibits the excitability of rat dorsal horn neu- rones produced by subcutaneous formalin inflammation. Pain 69:93-100.

Faber ES, Chambers JP, Brugger F, Evans RH (1997) Depression of A and C fibre-evoked segmental reflexes by morphine and clonidine in the in vitro spinal cord of the neonatal rat. Br J Pharmacol 120:1390-1396.

Filippov AK, Webb TE, Barnard EA, Brown DA (1998) P2Y $_{2}$ nucleotide receptors expressed heterologously in sympathetic neurons inhibit both N-type $\mathrm{Ca}^{2+}$ and M-type $\mathrm{K}^{+}$currents. J Neurosci 18:5170-5179.

Filippov AK, Webb TE, Barnard EA, Brown DA (1999) Dual coupling of heterologously-expressed rat $\mathrm{P} 2 \mathrm{Y}$ nucleotide receptors to $\mathrm{N}$-type $\mathrm{Ca}^{2+}$ and $\mathrm{M}$-type $\mathrm{K}^{+}$currents in rat sympathetic neurones. Br J Pharmacol 126:1009-1017.

Filippov AK, Brown DA, Barnard EA (2000) The P2Y ${ }_{1}$ receptor closes the $\mathrm{N}$-type $\mathrm{Ca}^{2+}$ channel in neurones, with both adenosine triphosphates and diphosphates as potent agonists. Br J Pharmacol 129:1063-1066.

Filippov AK, Simon J, Barnard EA, Brown DA (2003) Coupling of the nucleotide $\mathrm{P}_{2} \mathrm{Y}_{4}$ receptor to neuronal ion channels. Br J Pharmacol 138:400-406

Gu JG, MacDermott AB (1997) Activation of ATP P2X receptors elicits glutamate release from sensory neuron synapses. Nature 389:749-753.

Guo A, Vulchanova L, Wang J, Li X, Elde R (1999) Immunocytochemical localization of the vanilloid receptor 1 (VR1): relationship to neuropeptides, the $\mathrm{P}_{2} \mathrm{X}_{3}$ purinoceptor and $\mathrm{IB}_{4}$ binding sites. Eur J Neurosci 11:946-958.

Herlitze S, Gardia DE, Mackie K, Hille B, Scheuer T, Catterall WA (1996) Modulation of $\mathrm{Ca}^{2+}$ channels by $\mathrm{G}$ protein $\beta \gamma$ subunits. Nature 380:258-262.

Hille B (1994) Modulation of ion channel function by G protein-coupled receptors. Trends Neurosci 17:531-536.

Himmel HH, Kiss T, Borvendeg SJ, Gillen C, Illes P (2002) The argininerich hexapeptide $\mathrm{R}_{4} \mathrm{~W}_{2}$ is a stereoselective antagonist at the vanilloid receptor 1: a Ca ${ }^{2+}$ imaging study in adult rat dorsal root ganglion neurons. J Pharmacol Exp Ther 301:981-986.

Ingall AH, Dixon J, Bailey A, Coombs ME, Cox D, McInally JI, Hunt SF, Kindon ND, Teobald BJ, Willis PA, Humphries RG, Leff P, Clegg JA, Smith JA, Tomlinson W (1999) Antagonists of the platelet P2T receptor: a novel approach to antithrombotic therapy. J Med Chem 42:213-220.

Inokuchi H, McLachlan EM (1995) Lack of evidence for P2X-purinoceptor involvement in fast synaptic responses in intact sympathetic ganglia isolated from guinea-pigs. Neuroscience 69:651-659.

Kubista H, Lechner SG, Wolf AM, Boehm S (2003) Attenuation of the P2Y receptor-mediated control of neuronal $\mathrm{Ca}^{2+}$ channels in PC12 cells by antithrombotic drugs. Br J Pharmacol 138:343-350.

Kulick MB, von Kugelgen I (2002) P2Y-receptors mediating an inhibition of the evoked entry of calcium through N-type calcium channels at neuronal processes. J Pharmacol Exp Ther 303:520-526.

Lewis C, Neidhart S, Holy C, North RA, Buell G, Surprenant A (1995) Coexpression of $\mathrm{P}_{2} \mathrm{X}_{2}$ and $\mathrm{P} 2 \mathrm{X}_{3}$ receptor subunits can account for ATPgated currents in sensory neurons. Nature 377:432-435.

Malmberg AB, Yaksh TL (1994) Voltage-sensitive calcium channels in spinal nociceptive processing: blockade of $\mathrm{N}$ - and P-type channels inhibits formalin-induced nociception. J Neurosci 14:4882-4890.

Mintz IM, Adams ME, Bean BP (1992) P-type calcium channels in rat central and peripheral neurons. Neuron 9:85-95.

Moriyama T, Iida T, Kobayashi K, Higashi T, Fukuoka T, Tsumura H, Leon C, Suzuki N, Inoue K, Gachet C, Noguchi K, Tominaga M (2003) Possible involvement of $\mathrm{P}_{2} \mathrm{Y}_{2}$ metabotropic receptor in ATP-induced transient receptor potential vanilloid receptor 1-mediated thermal hypersensitivity. J Neurosci 23:6058-6062.

Nicholas RA (2001) Identification of the P2 $\mathrm{Y}_{12}$ receptor: a novel member of the P2Y family of receptors activated by extracellular nucleotides. Mol Pharmacol 60:416-420.

Okada M, Nakagawa T, Minami M, Satoh M (2002) Analgesic effects of intrathecal administration of P2Y nucleotide receptor agonists UTP and UDP in normal and neuropathic pain model rats. J Pharmacol Exp Ther 303:66-73.

Ralevic V, Burnstock G (1998) Receptors for purines and pyrimidines. Pharmacol Rev 50:413-492.

Roy ML, Narahashi T (1992) Differential properties of tetrodotoxinsensitive and tetrodotoxin-resistant sodium channels in rat dorsal root ganglion neurons. J Neurosci 12:2104-2111. 
Ruan HZ, Burnstock G (2003) Localisation of $\mathrm{P}_{2} \mathrm{Y}_{1}$ and $\mathrm{P} 2 \mathrm{Y}_{4}$ receptors in dorsal root, nodose and trigeminal ganglia of the rat. Histochem Cell Biol 120:415-426.

Sternweis PC, Pang IH (1990) The G protein-channel connection. Trends Neurosci 13:122-126.

Tominaga M, Wada M, Masu M (2001) Potentiation of capsaicin receptor activity by metabotropic ATP receptors as a possible mechanism for ATPevoked pain and hyperalgesia. Proc Natl Acad Sci USA 98:6951-6956.

Ueno S, Tsuda M, Iwanaga T, Inoue K (1999) Cell type-specific ATPactivated responses in rat dorsal root ganglion neurons. $\mathrm{Br} \mathrm{J}$ Pharmacol 126:429-436

Varadi G, Strobeck M, Koch S, Caglioti L, Zucchi C, Palyi G (1999) Molec- ular elements of ion permeation and selectivity within calcium channels Crit Rev Biochem Mol Biol 34:181-214

von Kugelgen I, Wetter A (2000) Molecular pharmacology of P2Y receptors. Naunyn-Schmiedeberg's Arch Pharmacol 362:310-323.

Vulchanova L, Riedl MS, Shuster SJ, Stone LS, Hargreaves KM, Buell G, Surprenant A, North RA, Elde R (1998) P2X X $_{3}$ is expressed by DRG neurons that terminate in inner lamina II. Eur J Neurosci 10:3470-3478.

Yoshida K, Nakagawa T, Kaneko S, Akaike A, Satoh M (2002) Adenosine 5 '-triphosphate inhibits slow depolarization induced by repetitive dorsal root stimulation via $\mathrm{P} 2 \mathrm{Y}$ purinoceptors in substantia gelatinosa neurons of the adult rat spinal cord slices with the dorsal root attached. Neurosci Lett 320:121-124. 